UC-NRLF

741 в 3893830

C6C5 


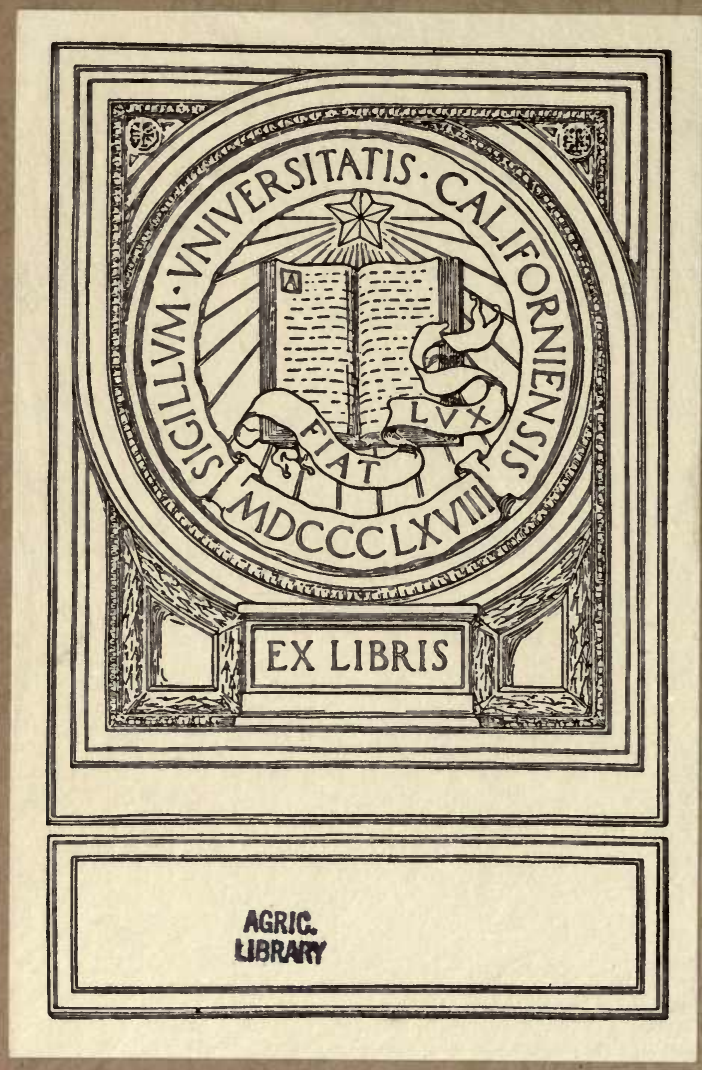




\section{STUDIES ON CLUBROOT OF CRUCIFEROUS PLANTS}

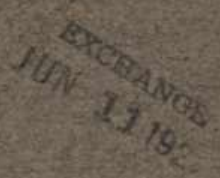

\section{A THESIS}

PRESENTED TO THE FACULTY OF THE GRADUATE SCHOOL

OF CORNELL UNIVERSITY FOR THE DEGREE OF

\section{DOCTOR OF PHILOSOPHY}

BY

\section{CHARLES CHUPP}

Published as N. Y. (Cornell) Agr. Exp. Sta. Bul. 387, 1917. 


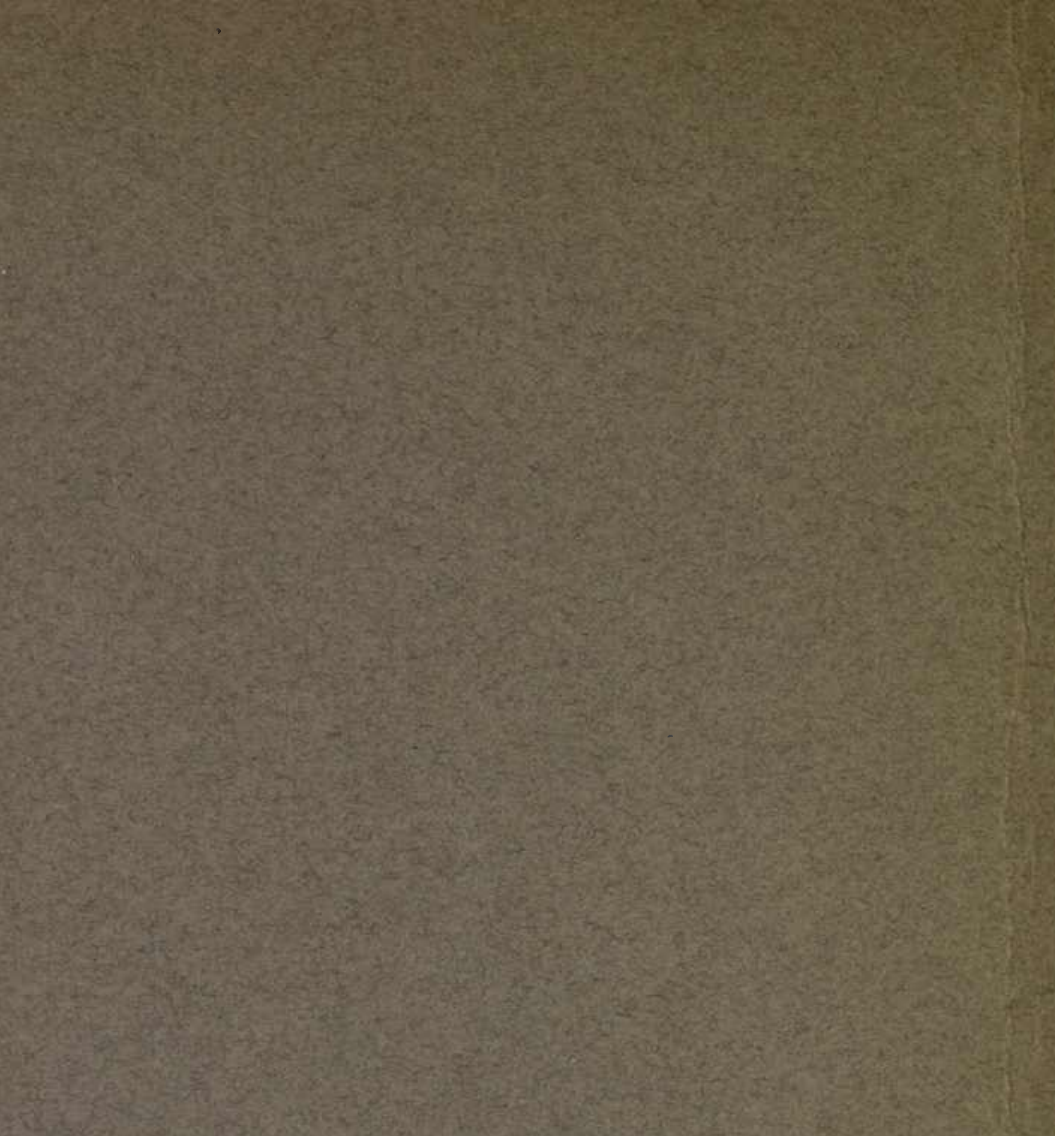
if

$40 x+505$

cosing

2010:30 


\title{
STUDIES ON CLUBROOT OF CRUCIFEROUS PLANTS
}

\author{
A THESIS \\ PRESENTED TO THE FACULTY OF THE GRADUATE SCHOOL \\ OF CORNELL UNIVERSITY FOR THE DEGREE OF

\section{DOCTOR OF PHILOSOPHY}

\author{
BY mic \\ CHARLES CHUPP
}

Published as N. Y. (Cornell) Agr. Exp. Sta. Bul. 387, 1917. 


$$
\begin{aligned}
& \text { SB } 741 \\
& C 6 C 5
\end{aligned}
$$




\title{
STUDIES ON CLUBROOT OF CRUCIFEROUS
}

\section{PLANTS}

\author{
CHARLES CHUPP
}


$\therefore \therefore$

\section{CORNELI UNIYERSTIT \\ AGRICULTURAL EXPERIMENT STATION \\ NeRIC. \\ EXPERIMENTUABRAR\&TAFF}

ALBERT R. MANN, B.S.A., A.M., Acting Director.

HENRY H. WING, M.S. in Agr., Animal Husbandry. T. LYTTLETON LYON, Ph.D., Soil Technology. JOHN L. STONE, B.Agr., Farm Practice.

JAMES E. RICE, B.S.A., Poultry Husbandry.

GEORGE W. CAVANAUGH, B.S., Agricultural Chemistry.

HERBERT H. WHETZEL, M.A., Plant Pathology.

ELMER O. FIPPIN, B.S.A., Soil Technology,

G. F. WARREN, Ph.D., Farm Management.

WILLIAM A. STOCKING, JR., M.S.A., Dairy Industry.

WILFORD M. WILSON, M.D., Meteorology.

RALPH S. HOSMER, B.A.S., M.F., Forestry.

JAMES G. NEEDHAM, Ph.D., Entomology and Limnology.

ROLLINS A. EMERSON, D.Sc., Plant Breeding.

HARRY H. LOVE, Ph.D., Plant Breeding.

ARTHUR W. GILBERT, Ph.D., Plant Breeding.

DONALD REDDICK, Ph.D., Plant Pathology.

EDWARD G. MONTGOMERY, M.A., Farm Crops.

WILLIAM A. RILEY, Ph.D., Entomology.

MERRITT W. HARPER, M.S., Animal Husbandry.

JAMES A. BIZZELL, Ph.D., Soil Technology.

GLENN W. HERRICK, B.S.A., Economic Entomology.

HOWARD W. RILEY, M.E., Farm Mechanics.

CYRUS R. CROSBY, A.B., Entomology.

HAROLD E. ROSS, M.S.A., Dairy Industry.

KARL McK. WIEGAND, Ph.D., Botany.

EDWARD A. WHITE, B.S., Floriculture.

WILLIAM H. CHANDLER, Ph.D., Pomology.

ELMER S. SAVAGE, M.S.A., Ph.D., Animal Husbandry.

LEWIS KNUDSON, Ph.D., Plant Physiology.

KENNETH C. LIVERMORE, Ph.D., Farm Management.

ALVIN C. BEAL, Ph.D., Floriculture.

MORTIER F. BARRUS, Ph.D., Plant Pathology.

CLYDE H. MYERS, M.S., Ph.D., Plant Breeding.

GEORGE W. TAILBY, JR., B.S.A., Superintendent of Livestock.

EDWARD S. GUTHRIE, M.S. in Agr., Ph.D., Dairy Industry.

JAMES C. BRADLEY, Ph.D., Entomology.

PAUL WORK, B.S., A.B., Vegetable Gardening.

JOHN BENTLEY, JR., B.S., M.F., Forestry.

EARL W. BENJAMIN, Ph.D., Poultry Husbandry.

EMMONS W. LELAND, B.S.A., Soil Technology.

CHARLES T. GREGORY, Ph.D., Plant Pathology.

WALTER W. FISK, M.S. in Agr., Dairy Industry.

ARTHUR L. THOMPSON, Ph.D., Farm Management.

ROBERT MATHESON, Ph.D., Entomology.

MORTIMER D. LEONARD, B.S., Entomology.

FRANK E. RICE, Ph.D., Agricultural Chemistry.

VERN B. STEWART, Ph.D., Plant Pathology.

IVAN C. JAGGER, M.S. in Agr., Plant Pathology (In cooperation with Rochester University).

WILLIAM I. MYERS, B.S., Farm Management.

LEW E. HARVEY, B.S., Farm Management.

LEONARD A. MAYNARD, A.B., Ph.D., Animal Husbandry.

LOUIS M. MASSEY,A.B., Ph.D., Plant Pathology.

BRISTOW ADAMS, B.A., Editor.

LELA G. GROSS, Assistant Editor.

The regular bulletins of the Station are sent free on request to residents of New York State.

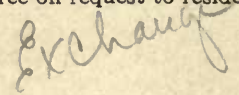




\section{CONTENTS}

PAGE

Dissemination. ............................ 42 I

Spore germination ........................ 423

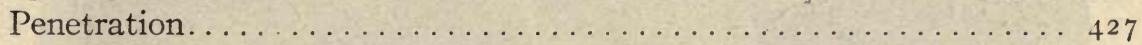

Distribution within the host tissues.................. 434

Spore formation and size . . . . . . . . . . . . . . . . . . . . 44

A similar organism............................ 442

Bacteria in relation to Plasmodiophora Brassicae............... 443

Summary.................................. 448

Bibliography.......................... $45^{\text {I }}$ 

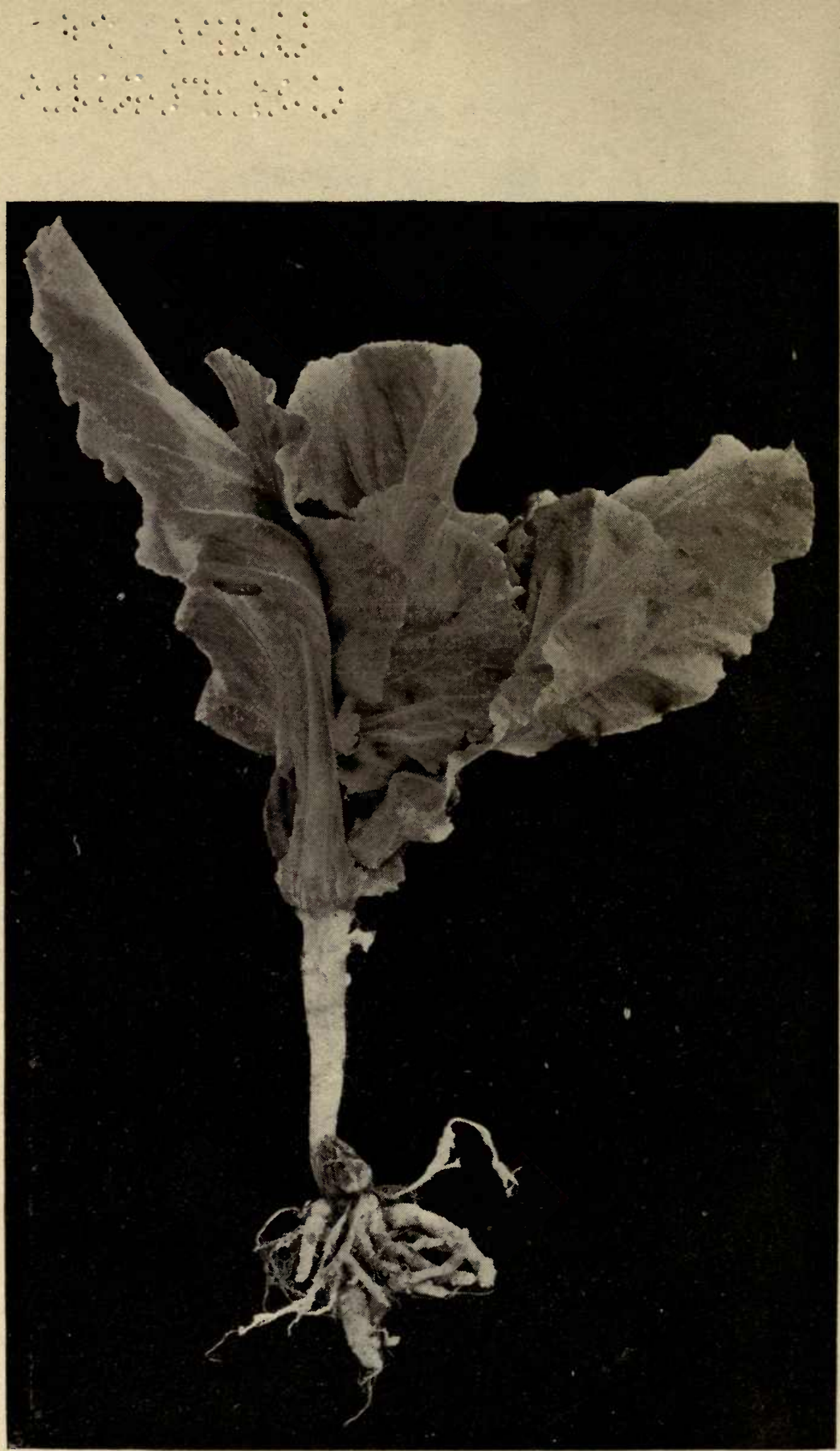

Fig. 95. Diseased CabBage PLANT SHowing The thin STALK AND THE ABSENCE OF A HEAD 


\section{STUDIES ON CLUBROOT OF CRUCIFEROUS PLANTS ${ }^{1}$}

\section{Charles Chupp}

- Such an extensive literature on clubroot of cruciferous plants has accumulated that it would seem impossible for any one point to have escaped careful consideration. But when a close examination is made of all the data, it soon becomes apparent that only such prominent phases as symptoms, cytology of the organism, and control methods, have been dealt with extensively, while certain other less conspicuous features have been neglected. There still remain to be satisfactorily solved the following problems: (a) the part played by swarm-spores in the dissemination of Plasmodiophora Brassicae Wor., the organism that causes clubroot; (b) spore germination; (c) the manner in which the pathogene enters the host; (d) the distribution of the organism thruout the tissues of the root; (e) formation and size of the spores; and (f) the relation of bacteria to the normal development of the myxomycete. It is for the solution of these problems that the following investigations have been conducted.

\section{DISSEMINATION}

In a general way the manner in which the spores are carried is known, altho two errors are often met with in popular descriptions. For example, in a number of reports (Atkinson, I889, Carruthers, 1893 , and others) ${ }^{2}$ are statements implying that swarm-spores swim about in the water of the soil until they reach a cabbage root. In a way this is correct, but the average layman at once pictures the swarm-spores as traveling from row to row of plants or even from field to field. Nothing could be more erroneous, for, as far as dissemination is concerned, the motility of the swarm-spore plays such a slight part that it need not be considered. Its energy is not directed in a straight line, and the very minuteness of the organism would preclude any effective locomotion in the time that it remains alive.

In order to test the distance to which swarm-spores may travel in the soil, a box two feet square was filled with clay mixed with muck soil, and diseased roots were buried in one end. Cabbage seeds were then sown in the box, care being taken not to transfer any of the soil from the place where the inoculum was inserted. When the seedlings over the area

\footnotetext{
I Also presented to the Faculty of the Graduate School of Cornell University, September, I9r6, as a major thesis in partial fulfillment of the requirements for the degree of doctor of philosophy.

ACKNOWLEDGMENT. The author gratefully acknowledges the helpful suggestions and criticisms offered him by Professor H. H. Whetzel and others in the Department of Plant Pathology at Cornell University.

:Dates in parenthesis refer to bibliography, page 451 .
} 


$$
\begin{aligned}
& \because \therefore \vdots \because \because \because \cdots, \cdots \cdots \\
& \text { BULLETIN } 387
\end{aligned}
$$

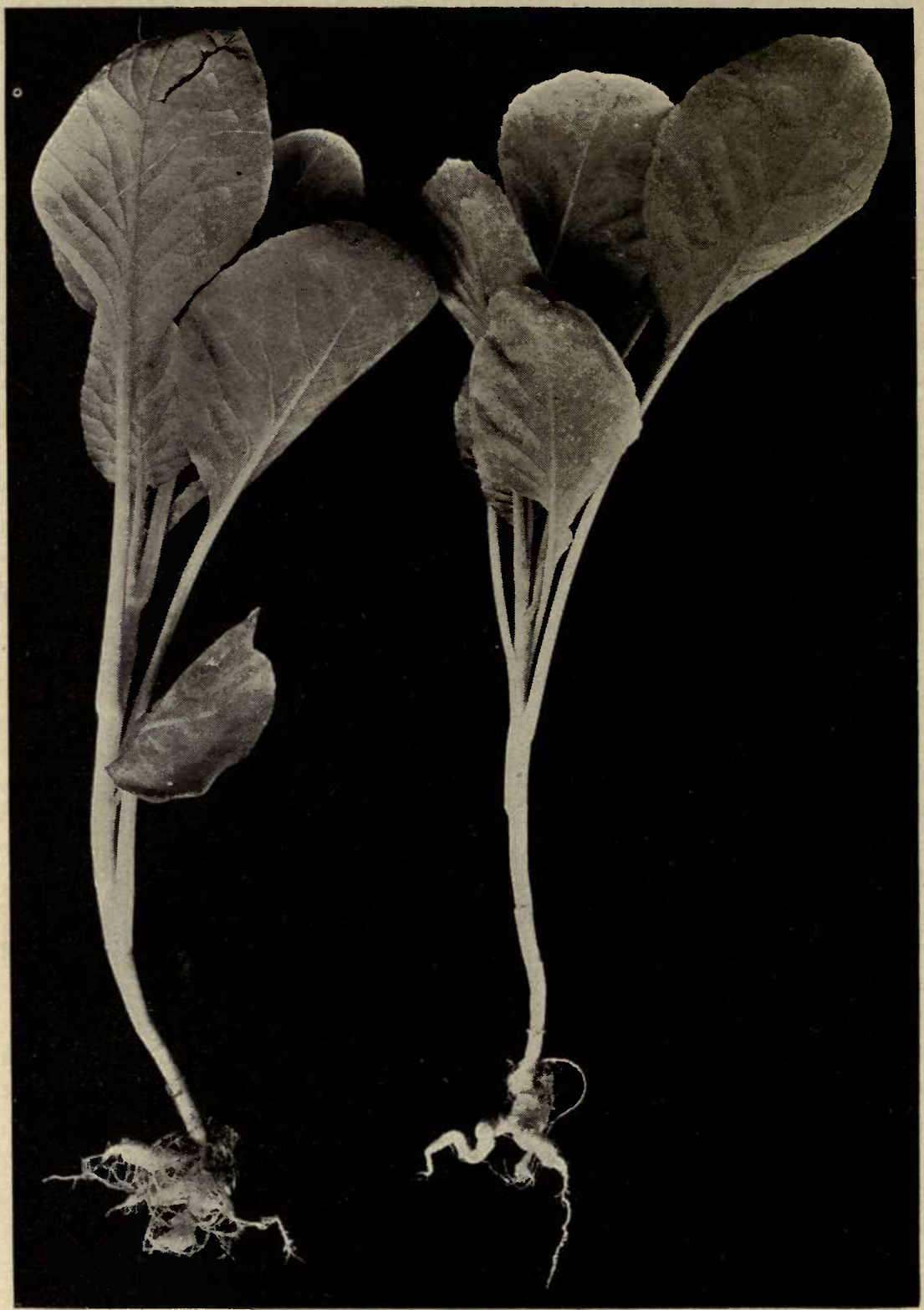

Fig. 96. DISEASED CABBAGE SEEDLINGS 
where diseased roots were buried had become so badly infected that they began to wilt and turn yellow, all the plants were discarded and the plat was reseeded. Different crops of seedlings were thus grown for almost a year, and, altho there was a gradual spread of the organism, it was only by careless watering and planting that the pathogene was carried in the soil to all parts of the box.

Cabbage seeds were sown in a greenhouse plat in rows ten inches apart, the bottom of each trench being first lined with infested soil. Halfway between these rows were sown other rows, in the trenches of which no infested soil was placed. The inoculated plants (fig. 96) became infected at a very early stage, while the plants that were only five inches away from the spores remained healthy until they were almost mature.

A few authors (Carruthers, I893, and others) claim that wind is an important agent in spore dissemination. This may be true in light, loose soil, and in localities where strong winds prevail, but in none of the observations made by the writer was there a single case in. which the presence of the organism could be explained on this basis. On the other hand, many of the fields showed that if the soil were not transferred by some agent other than the wind the pathogene did not spread. On Long Island, New York, a certain field was observed, one corner of which was slightly lower than the adjoining part. This corner had been used for a garden until clubroot became so prevalent that the plat was no longer profitable for the raising of crucifers. It was then tilled with the remainder of the field for three years while various crops were grown, cabbages not being planted again until the fourth year. A space only slightly larger than the original garden then displayed the presence of clubroot. If wind had been an important agent it would have had an opportunity here, for the land was almost level and the soil was very loose. This was only one of several cases in which the same conditions were observed.

\section{SPORE GERMINATION}

Very few persons have been successful in germinating the spores of Plasmodiophora Brassicae, and of those few who have been so fortunate, still fewer have seen the actual process. Woronin (1878) gives a brief description and a series of illustrations which have been copied by nearly all later writers on this phase of the subject. The general experience, however, seems to have been like that of Maire and Tison (I9II) while working with Tetramyxa parasitica Goebel. They saw only one spore actually germinating, and after a very long, tiresome vigil they left it for a few minutes. On returning from their temporary absence they found that the phenomenon had been completed. Notwithstanding these diff- 
culties, Eycleshymer (1894) not only found swarm-spores, but also found that when left in the culture for a few days these apparently fused into larger bodies, thereby reacting in much the same manner as Kunkel (I9I5) found to be the case with Spongospora subterranea (Wollr.) Johnson. Kunkel discovered that each cell of a spore ball produces a single uninucleate amœba which soon fuses with others of its kind to form a small plasmodium. This occurs not only in the case of spores in the soil, but even with those still in the base of the old sorus.

There are several obstacles to be encountered in trying to observe the actual emergence of the protoplasmic mass from the old spore wall. First, it is difficult to get a very large percentage of germination unless the most favorable conditions are present. Secondly, all observations must be made with the oil-immersion objective. When the protoplasm is about halfway out, the spore wall and the emerging protoplast begin to move, making it hard to keep them in focus or even within the field. Consequently, when the process seems almost complete there is a sudden swift whirl, and the swarm-spore, with the adhering empty wall, darts out of sight. When located again, the spore wall is empty, and the swarm-spore, lost among others, is impossible of identification. For this reason no actual separation of the protoplasm from the spore wall has been seen, but enough of the process has been observed to enable investigators to determine the general method by which this is accomplished and to be sure that a spore gives rise to only one swarm-spore.

It was soon learned that spores do not germinate well, if at a'l, in distilled water, and further that, altho from one to five per cent of the spores taken directly from a fresh root germinate in muck-soil filtrate, a much larger percentage of germination can be obtained by exposing the roots to freezing temperatures for two weeks or longer. This was accomplished by tying the roots in cheesecloth and burying them under the snow, or in summer by keeping them in the refrigerator for that length of time. Drying the roots also seems to have a beneficial effect on germination, altho this must not be carried to the extreme. The muck-soil filtrate was made by filling an ordinary flowerpot with muck, placing it over a large funnel lined with filter paper, and then pouring hot water on the soil. The resulting medium was of an amber color and slightly acid.

Temperature conditions also influence germination of the spores. It was practically impossible to obtain infection in the greenhouse during the coldest winter months when the temperature was from $10^{\circ}$ to $18^{\circ} \mathrm{C}$. The spores also fail to germinate at ordinary room temperature (from $16^{\circ}$ to $2 \mathrm{I}^{\circ} \mathrm{C}$.). The optimum temperature for germination proved to be from $27^{\circ}$ to $30^{\circ} \mathrm{C}$. This, however, is not the case when spores are placed in test tubes on agar with young cabbage scedlings, for under such conditions 
infection takes place at a temperature of from $16^{\circ}$ to $21^{\circ} \mathrm{C}$. The presence of the host seems in some manner to exert an influence which to a certain extent takes the place of that offered by a greater amount of heat.

Usually the first sign of germination is a swelling of the spore, which sometimes becomes a third larger. This occurs within a period of from fifteen minutes to eight hours after the spores are placed in the medium, altho the best time for examining the culture proved to be at the end of six hours. After the swelling of the spore there is a bulging at one side. The protoplasm withdraws from near the opposite wall and leaves a nearly hyaline semicircle about two-thirds of the distance from the center. The pressure exerted splits the wall just enough to permit the protoplasm to ooze out. Unlike Woronin (1878) and Mangin (I902), the writer has never observed the protoplasm taking the various shapes that these authors assign to it, but while oozing out it collects in a sphere or a hemisphere against the wall on the outside. When about half of the protoplasm has escaped, the whole body becomes motile. At first there is only a trembling, which gradually increases in violence until the spore is turned around entirely. The activity now becomes so great that it is with diffculty that the microscope is kept focused on it correctly. The final struggle is apparently a rapid spurt across the field, when the swarm-spore is liberated from its container and at once begins its rotatory activities. The whole process under the microscope consumes an hour or longer. Evidently the strong light turned on a spore retards the action, for in many cases the spores that had begun to germinate when placed in view showed no further signs of development, while those kept in the dark germinated much more rapidly and when examined at the end of the same period were found actively swimming about.

A considerable part of the contents is left within the old spore wall, so that when the broken part is turned upward it has the appearance of a circle bounded by a darker band, the width of which is about one-third of the radius. If, however, the open part is on the side, the residue within the spore wall resembles more nearly a crescent (fig. 97).

The swarm-spore when alive measures from I.7 to $3.5 \mu$ in length, being more or less pyriform with a thick flagellum at the smaller, or anterior, end and a vacuole near the posterior end. Unless stained, the flagellum cannot be seen under the microscope. The line of locomotion is never a straight one, for the flagellum is lashed about by the beak, which is constantly doubling backward so that a whirling motion is given to the swarm-spore. Altho the latter is a naked mass of protoplasm, the writer has never seen the various shapes which Woronin (1878, Pl. xxxIv) has pictured; it was observed in every case to be globose or pyriform, never having pseudopodia-like structures. 
It has been difficult to properly fix swarm-spores for staining flagella. The first method of staining tried was that ordinarily employed for bacteria, namely, Loeffler's mordant and Ziehl's carbol fuchsin. When bacteria were in the mount their flagella were stained, but those of the

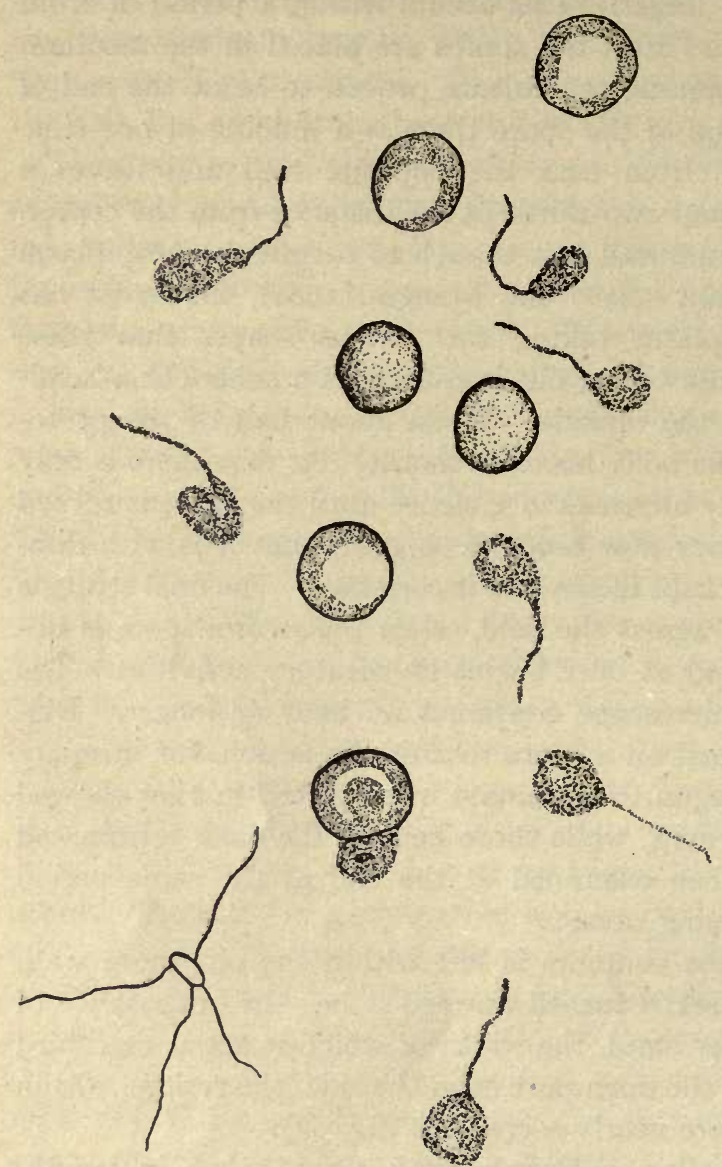

FIG. 97. SPORES AND SWARM-SPORES OF PLASMODIOPHORA BRASSICAE

The two spores at the top have already germinated. The germinating spore and the two swarm-spores near the bottom were drawn from stained mounts. The bacillus shown is the form found oftenest in older diseased roots. $\times 2100$ swarm-spores had evidently disappeared. The process was then modified slightly, and the cover-glass mounts, instead of being left to dry in the incubator, were placed on slides in preparation dishes with ground-glass tops. In the bottom of each dish was placed a few cubic centimeters of osmic acid, and the lid was then carefully fitted in place. The acid killed a few of the swarmspores before the flagella could be withdrawn, but never a very large proportion. Besides demonstrating the presence of flagella, the stained material also displayed different stages of germination (fig. 97).

Kunkel (I9 I 5) was able to get spore germination of Spongospora subterranea on an agar medium. Plasmodiophora Brassicae evidently does not react in the same way. During the three years of the present work, repeated efforts were made to secure not only germination on the surface of agar, but also formation of plasmodia. Unless the spores were immersed in water there was no development. They lay there until the agar became so dry that they finally lost their viability. If enough of the muck-soil filtrate was added, the swarm- 
spores appeared but there was no further development. They were active for a certain time, and then encysted and remained in that condition as long as the cultures were kept. This experiment was performed on four kinds of agar media, on potato plugs, and on healthy cabbage roots. In no case were there any signs of further growth. This, with subsequent infection experiments, indicates very strongly, if it does not prove positively, that the swarm-spores never fuse. This is in keeping with what has been found, or at-least suggested, in all other cases of parasitic slime molds, Spongospora subterranea excepted.

If spores for germination are taken from roots that have not previously been disinfected, there are often found in the cultures flagellate bodies which are almost small enough to resemble

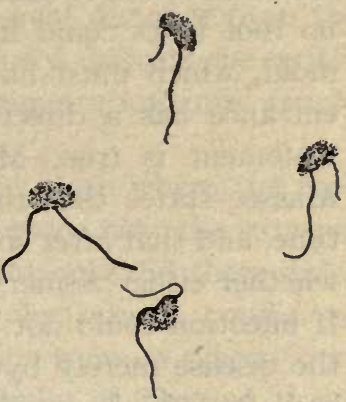

Fig. 98. FLAGELLATE ORGANISMS A S SOCIATED WITH PLASMODIOPHORA BRASSICAE swarmspores. They are larger, however, are more active, and when stained are more or less reniform, having two flagella arising from the concave side (fig. 98). These, as pointed out later, belong to another organism.

\section{PENETRATION}

In the knowledge of the life history of Plasmodiophora Brassicae, there has always been a gap between the swarm-spore stage and the amoba within the cell, the true sequence of development never having been shown. Most writers pass over the difficulty with the mere statement that the organism enters the root and there begins its parasitic life. Woronin ( 1878$)$, in this as in nearly all other points connected with clubroot, is the only one who has tried to fill in the gap. In a way he succeeded, but, as his plants died before reaching the stage in which invasion of any of the tissue took place, he is not sure that the root hair is the real point of entrance. He placed cabbage seedlings in shallow watch glasses, in water well supplied with spores. For some reason the plants began dying before hypertrophy took place. When the roots were examined microscopically, the root hairs were filled with amœbæ but nothing further had happened. The question still remained, whether these infections under normal conditions would have been followed later by invasion of the cortical cells, or whether the case was similar to that which Schwartz (rgr4) found in species of Ligniera. Schwartz thinks that penetration takes place near the apex of the root, so that when the root hairs act as bearers of the amœbæ the parasite does not advance farther than the base of the cell.

Most writers believe not only that the apical cells and the root hairs act as infection courts, but also that the epidermal cells can be infected 
directly up to the time when the epidermal layer is thrown off (Woronin, r878). Somerville ( 1895 ) gives an observation as proof of this statement. He often found swellings high up on the roots of turnips, where he declares no root hairs could have been responsible for the entrance of the slime mold, which must have penetrated the thick cuticle. This question of entrance has a direct economic bearing on control, for, if Somerville's statement is true, Massee's (1903) assumption is certainly erroneous. Massee states that the Cruciferæ can be attacked only during seedling time, and that after six weeks they are practically immune. It is doubtful whether either Somerville or Massee interprets the conditions correctly. If infection could not take place after six weeks, the grower could control the disease merely by late transplanting and the proper care of his seed beds; but this has evidently not proved to be the case in practice.

Maire and Tison (1909, I9II) and Schwartz (I9I0, I9II, I9I4) have done nearly all the work that has been reported on the parasitic slime molds other than Spongospora subterranea and Plasmodiophora Brassicae. It is interesting to note that their conclusions agree very closely, and that they feel sure the amœbæ enter oftener thru the apical cells than otherwise, altho the root hairs also may serve as points of entrance. They made no particular study of this question, but were led to this conclusion by finding uninucleate amobæ in the cells near the growing tips. Their opinion is substantiated also by the presence of rows of diseased cortical cells, the divisions of which apparently take place when still very near the initial cells in the root tips. The powdery scab pathogene, Spongospora subterranea, passes directly thru and between the epidermal cells into the tuber (Kunkel, igi 5 ).

There is more or less difficulty in studying the nature of penetration in the case of Plasmodiophora Brassicae, because of the fact that the uninucleate amœbæ are so small. They can be recognized only under a very high magnification, and, since they are so nearly transparent, stained sections must be used for all the work. A very large number of both longitudinal and cross sections were prepared, the thickness ranging from three to fifteen microns, and the staining was done with the combination stains of safranin, gentian violet, and orange $G$. These proved best for differentiating the parasite from the host, especially when orange $G$ was used in excess.

There is no possible stage in penetration that was not represented in the preparations. Large, as well as very small, roots were sectioned, and a great number of epidermal cells showed amœbæ. But in a careful study of almost three hundred slides, none of these cells showed that penetration had taken place directly thru the cutinized wall. In a number of cases this appeared to be true when the sections were first examined, 
but a more detailed study of the same series showed the invaded cell to be in every case the basal portion of a root hair. This, together with the fact that no new swellings are ever found at any great distance from the region where root hairs might have existed previously, has led the writer to believe that seldom, if ever, is there direct penetration into simple epidermal cells.

This holds true not only for the area above the place where the root hairs have disappeared, but evidently also for the space near the extreme tips where the hairs have not yet been formed. Not only did these slides demonstrate this point, but infection secured under aseptic conditions in test tubes has confirmed it. The small root-tips were so placed that they were the first to come into contact with particles of diseased tissue and the muck-soil filtrate containing free spores. When these rootlets were sectioned and stained, they showed various stages of root-hair invasion, but no a $m œ b æ$ we re found in any of the apical cells. The evidence presented in these slides shows that these invasions are not, like those which Schwartz (I9I4) suggested for Ligniera sp.,

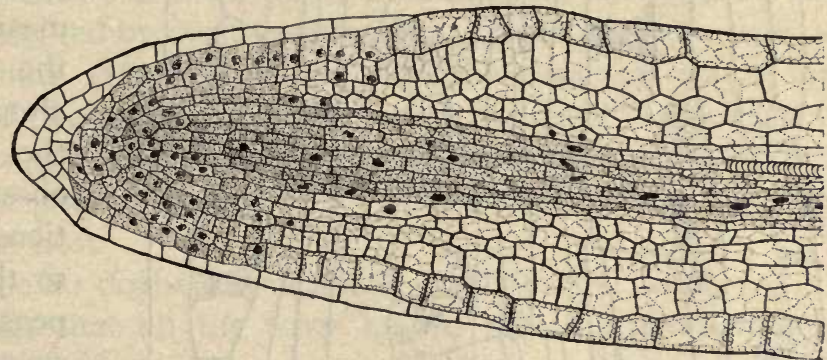

Fig. 99. LONGITUdinal SECtion OF A CABbage ROOT

This shows the tip of the cabbage root protected by the cells of the rootcap. $\times 110$

confined alone to the epidermal cells of which the hairs are outgrowths. The passage of amobæ from the epidermal cells into the cortical tissue is demonstrated not only by the position of the amobæ within the parenchyma cells, but also by actual cell-wall penetration.

The argument advanced for other species of Plasmodiophoracex, that infection must take place in the growing tip where cells are dividing rapidly because the organism often occurs in definite rows of the cortical cells, does not neceśsarily apply to Plasmodiophora Brassicae. A glance at a section of a root tip (fig. 99) indicates the difficulty that a swarmspore would encounter in entering at this point. The rootcap does not merely protect the root tip, but a row of its cells extends upward almost halfway to the root hairs. The remaining distance is protected by a comparatively heavy cuticle, leaving the root hair as practically the only vulnerable point. Moreover, the presence of the organism in continuous rows of cells can be explained in another manner. The condition shown 
in figure $100, \mathrm{~B}$, gives no indication as to where penetration occurred. Yet by moving the section the length of half a dozen cells, there is seen an uninterrupted connection of diseased tissue between this particular
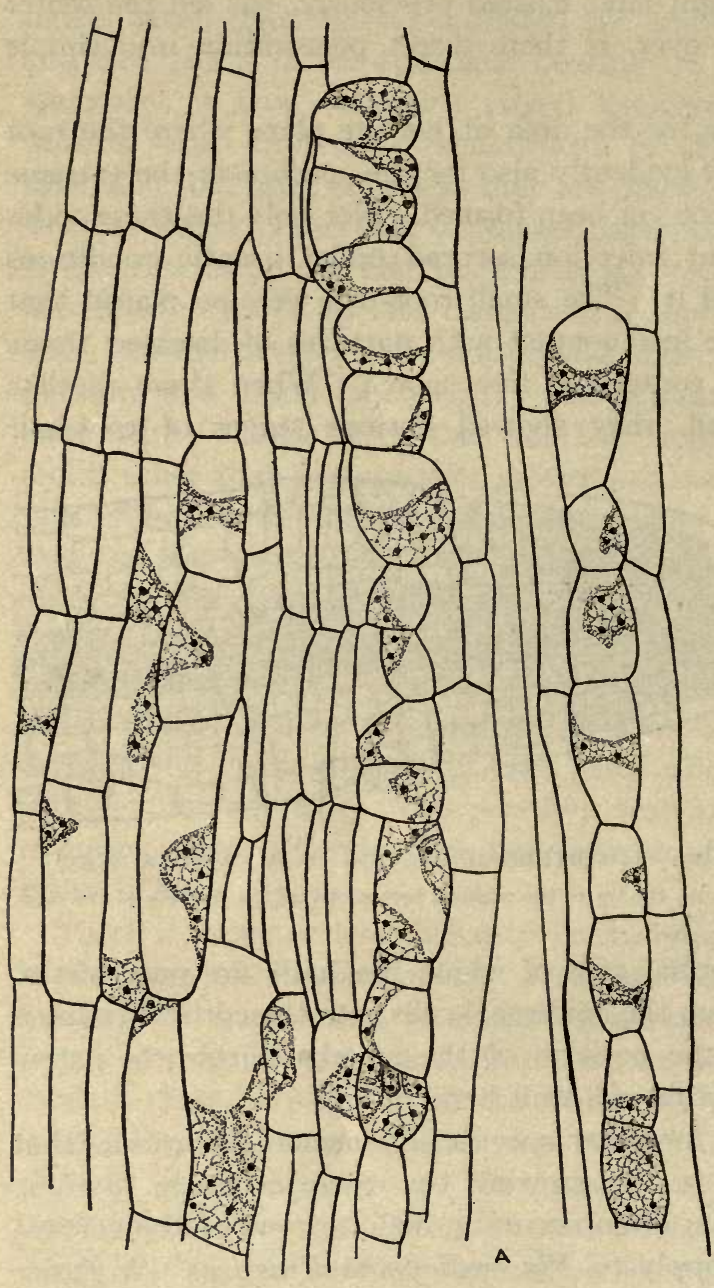

Fig. IOO. Diseased CORTICAL TISSUE OF a CABbage ROOT

A, A row of diseased cortical cells; B, another row of diseased cortical cells connected with the epidermis by an unbroken line of diseased tissue. $\times$ I 10

bacteria were deprived of oxygen. were produced in the roots is unusually short. He gives it as five days, in which he claims spores

row and the epidermis (fig. I00, A).

So far as the writer's observations go, there seems to be no question but that penetration does take place thru the root hairs, and thru these only. Eycleshymer (1894) suggests that wounds caused by insects may provide a means of entrance for the parasite. This is altogether probable; yet the writer has never observed any indications of this condition, so that if it ever happens it apparently does so very rarely. If cultures could be secured within pieces of healthy disinfected roots in test tubes, it would at least be evidence that such wound infection might take place. Pinoy (I905) removed small pieces of nealthy roots by means of sterilized pipettes, and by inoculating them with spores secured cultures of the organism, provided the tubes were sealed so that the aerrobic His discussion of this point is some- 
which is the same time that under the most favorable circumstances it takes swarm-spores to pass thru the root hairs into the cortical tissue and to develop sufficient hypertrophy to be visible to the naked eye. Kleimenov (I9I2) tried the same experiment and failed. In the writer's experiments it was also tried repeatedly, always with failure. If the cultures were kept free from bacteria the root underwent no change. If bacteria were added, the root became soft and foul-smelling, whether the test tubes were closed with cotton plugs or sealed with paraffin over cork or cotton stoppers. Sealing did not stop the growth of the bacteria, as Pinoy claims for his experiments.

Altho authors popularly describe with some assurance various ways in which the organism may enter the host, no one has observed the real process. Even Woronin, who believed that the organism passes thru the root hair, was never able to demonstrate this clearly. Nevertheless he fe't assured that it enters in the form of a uninucleate amoba, and his o jinion has been accepted by most investigators. A few workers, such as Worthington G. Smith ( 1884 ), maintain that the organism enters the root in the form of a plasmodium, but this theory has never been accepted generally. The question was revived again when Kunkel (I9I5) studied the powdery scab of potato, in which the swarm-spores are found to fuse before attacking the host.

There seems to be no doubt in the minds of Maire and Tison (IgII) and Schwartz (I9I4) that all the other known parasitic myxomycetes enter immediately after the swarm-spore stage. This conclusion is based on the fact that many of the slides of these investigators show the uninucleate forms in the apical cells. There is no other theory that would explain this phenomenon, unless a single uninucleate amœba of an infecting plasmodium passes thru the intervening cell walls and spreads in this manner thru the tissue. This is improbable.

Because of the diminutive size of the swarm-spore, the only satisfactory method for studying penetration appears to be by means of stained sections of roots showing the earliest stages possible. In the first part of this work, young plants from the greenhouse were used, but none of the stages were young enough to give just what was desired. An attempt was then made to grow plants in large test tubes on screens so arranged that the roots were hanging in muck-soil filtrate containing a heavy suspension of spores. The roots did not develop well when immersed in the liquid medium, and but few root hairs were present. An attempt was then made to grow seedlings in soil, in flats six inches square, with diseased tissue so plentiful that none of the plants could escape infection. The roots were fixed and embedded at intervals before the time when ordinary symptoms became apparent to the naked eye. This gave nearly all the early stages 
of infection, but the adhering particles of soil, which could not be washed off without sacrificing the hairs, not only were detrimental to the microtome knife, but also obstructed a clear view of the cell walls. Finally a method was devised whereby infected roots could be procured free from any other contamination. Diseased roots that contained spores but were not far enough advanced to be invaded by bacteria were sterilized on the surface with mercuric chloride and transferred to agar slants in test tubes. After two weeks cooling in the ice chest they were finely minced in the agar,
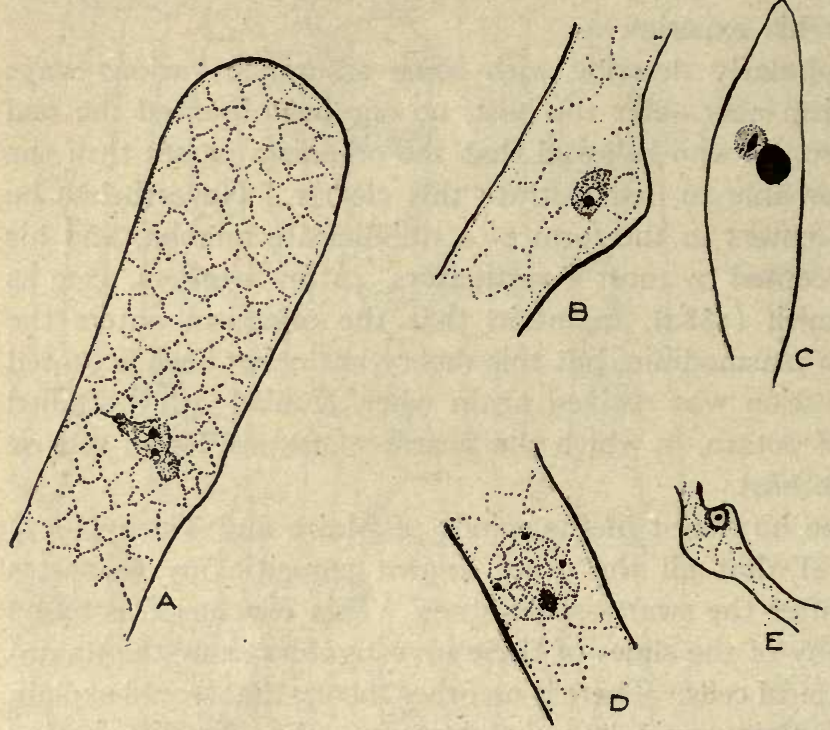

FIG. IOI. THE AMCEA OF PLASMODIOPHORA BRASSICAE IN A ROOT HAIR

A, A root hair with an amœba showing two nuclei. B, A uninucleate amoba in a root hair which shows an abnormal swelling in the immediate vicinity of the organism. C, A uninucleate amœba in a tangential section of a root hair; the nucleolus has elongated, as it ordinarily does just before nuclear division. D, A host nucleus in a root hair, showing its size as compared with that of a uninucleate amœba. E, A uninucleate amoba in a shrunken, distorted root hair. $\times 1600$

liquid to permit spore germination and not have an excess, which would injure the root. A few drops would not evaporate until all the swarmspores had ample time to be set free and attack the root hair. The process 'was somewhat long, and very often roots were chosen which were too old and were already contaminated with bacteria. In spite of all the difficulties, enough pure cultures were obtained to provide a large number of sections which showed all sizes of amobæ.

The first and most important thing shown by the stained sections was that Plasmodiophora Brassicae enters the root hair as a uninucleate amœba, 
not as a plasmodium. There are several facts that prove this conclusively, even tho the actual phase of the organism passing thru the wall was never observed with certainty. A number of slides show cases that might be interpreted as actual penetration, but as the nucleus in no case appears in the act of making the passage one cannot be certain of such an interpretation. Nevertheless, numerous cases are to be found of a uninucleate amœba just within the wall of the root hair and far enough away from any other infection to preclude all possibility of its having reached there except by entering singly thru the wall (fig. Ior).

Evidently the reason why no one has recorded this stage heretofore is because the amoba hardly enters before nuclear division and growth takes place. Some slides show binucleate amœbæ still within the hollow of the enlarged cavity, apparently produced by the stimulus of the parasite. Other sections show trinucleate amobæ, and it is not difficult to find amœbæ with six or more nuclei (fig. 104, page 436 ).

This series of stages would indicate that penetration takes place in the uninucleate stage, particularly since the large multinucleate amœbæ are to be found, in nearly every instance, near the base of the root hair, while the smaller and fewer-nucleate amœbæ are always on the inside of the root-hair wall about two-thirds of the distance from the base. Amœbæ are seldom found in the tip of the hair.

Another point that confirms the above view of penetration is that in the absence of growing host roots the swarm-spores develop no further when the spores are germinated under artificial conditions, and after a short period of activity the swarm-spores encyst and eventually die. If plasmodia are formed under normal conditions, there should have been at least a suggestion of this in a few of the numerous cultures used in the experiments.

In this connection also the very interesting question of sexual fusion arises. It is believed by several cytologists that there are two nuclear divisions just before spore formation and that one of these is probably a reduction division. If this is true, it would imply that somewhere in the life cycle there has been a fusion. Winge (I9I3) and others believe that this occurs among the swarm-spores before they enter the host. Prowazek (1905) is of the opinion that the amobre within the host unite and then the nuclei fuse. Even Nawaschin (1899) believes this union takes place, but apparently he thinks it is of no significance in reproduction. Maire and Tison (I909, I9I I) have disproved the amobal union, and their view is certainly correct, for it is possible to find slides showing one amoba breaking up into spores while in another, immediately adjoining, division 
has not yet begun (fig. 102,D). On the other hand, it would seem that the fusion of two swarm-spores would give an increase in size, but the measurements of amobæ just after penetration show them to be no larger than the swarm-spores just out of the spore wall. Consequently Winge's theory
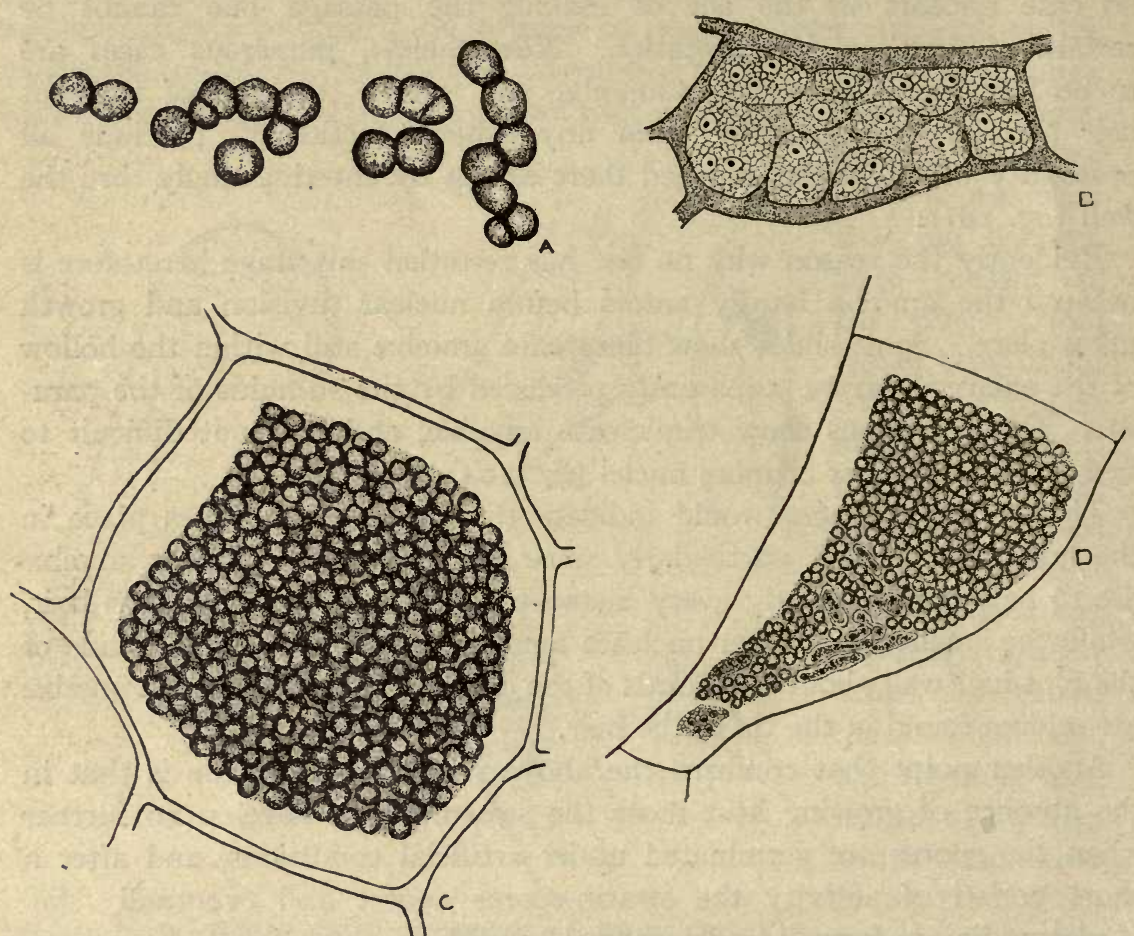

FIG. IO2. SPORES AND AMEBE OF PLASMODIOPHORA BRASSICAE

A, Spores before their final separation from one another; B, cell filled with amœbæ; C, cell filled with spores. All $\times 800$. D, Formation of spores, $\times 500$

must be discarded. It thus appears that the real fusion stage, if there is one, is still to be discovered.

\section{DISTRIBUTION WITHIN THE HOST TISSUES}

As stated above, the uninucleate amœba, just after its entrance into the host, lies at first in a small cavity produced by the outward swelling of the part of the root hair at the point where the organism entered. This protuberance is no doubt caused by the irritating presence of the parasite (fig. IOI, A, B, E). Following penetration the amœba increases in size and pushes toward the center of the hair. The movement is accomplished by an actual amœboid creeping, and an elongation and gradual segmentation of the forward part. Woronin ( 1878 ) was able to observe the 
former method of locomotion in the living cells, and mentions it as the means by which the organism moves. Schwartz (I910), on the other hand, observed the growing of the amœboid tip in Ligniera Junci (Sch.) $\mathrm{M}$. et $\mathrm{T}$., and explains the change of position on that basis alone. A root hair is shown in figure 104, D, which apparently was infected near the tip, and as the organism grew rootward fission took place, so that when the anterior part of the amœba eventually reached the base of the cell the root hair was filled completely with the meronts, as Maire and Tison (I9I I) designate the segmented parts (fig. I03). This does not always take place, for there were many more cases observed in which the intact amœba reached the base of the cell (fig. I04, E, F). In either case, if the time consumed is too long, or if for any other reason sporulation begins, the amœba loses its power of further penetration into the cortical tissues. If, however, it reaches the inner wall of the root-hair cell, its pseudopodia are extended into the very smallest thread-like processes, which pass thru and into the cortical cell (fig. I05, E, F, G). Schwartz (1910), in describing penetration by Ligniera Junci, gives the same route of invasion but does not state how the passage from the epidermis into the cortical cells takes place. This question is of especial interest, since in the

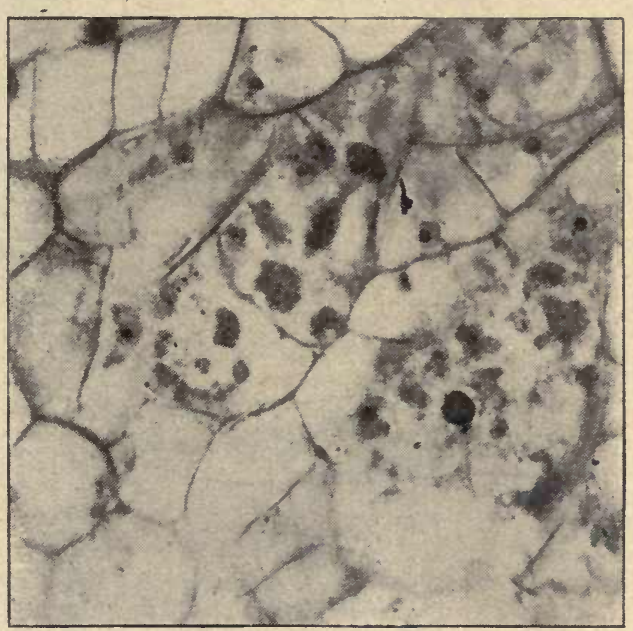

Fig. IO3. PHOTOMICROGRAPH OF CELLS CONTAINING AMGEB

latter part of his discussion Schwartz states his belief that amœbæ never have the power of penetrating cell walls. There is no other apparent means by which this could be accomplished, for the epidermal cells seldom divide periclinally.

It would be difficult to explain the wide distribution of the parasite within the root if cell-wall penetration did not occur, even tho it were taken for granted that invasion begins in the apical cells. The rootcap so fully protects these rapidly dividing primary cells that one must presuppose that in order to reach them the organism can pierce the walls. Then, in the maturer roots constant secondary thickening by the cambium takes place, which would ultimately push most of the diseased cells toward the periphery or isolate them near the center. This, however, does 

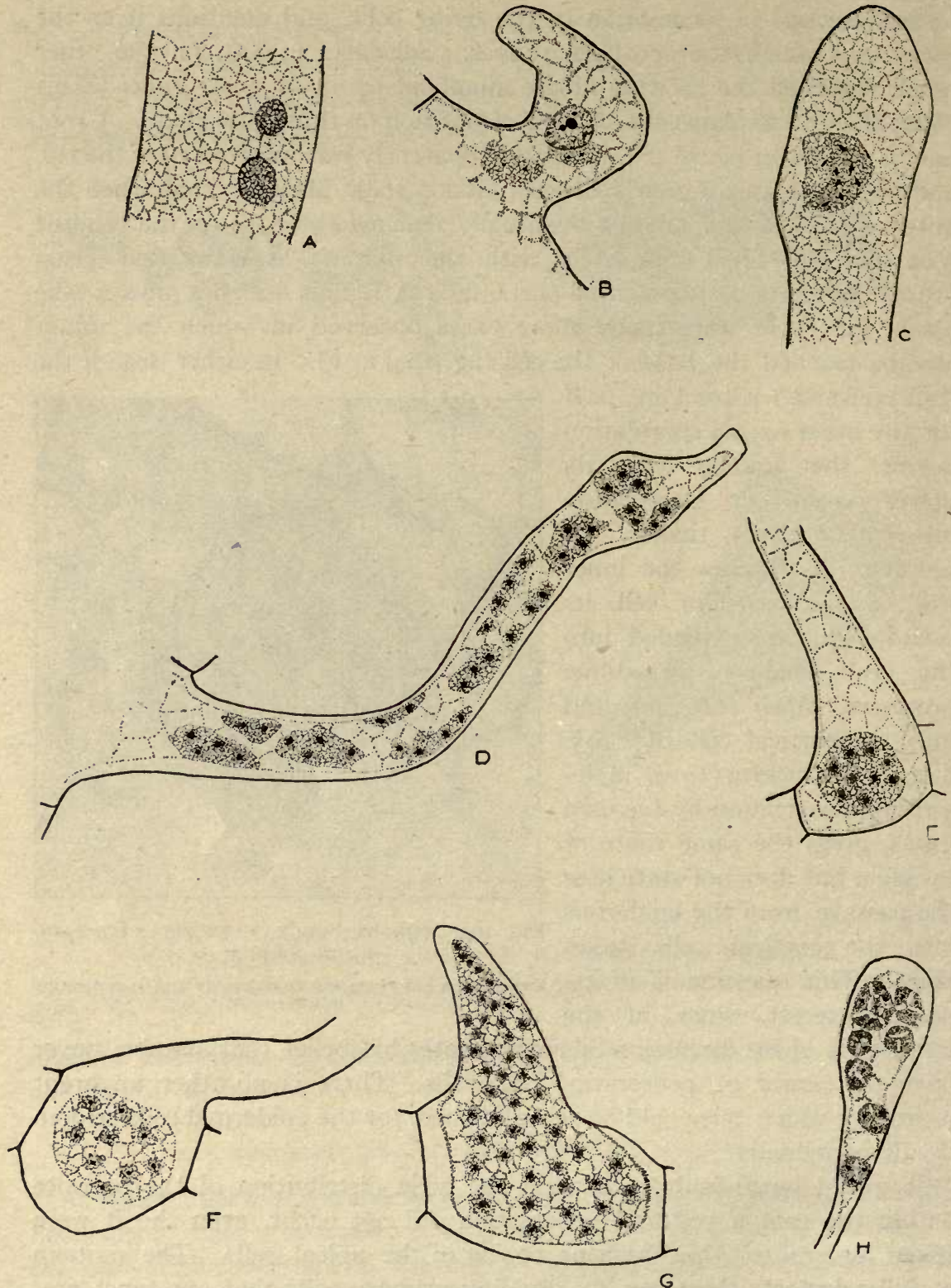

Fig. 104. SECTIONS OF CABBAGE ROOT HAIRS SHOWING AMCEBAE

A, An amoba dividing by fission in a root hair. B, A much distorted and swollen root hair, with a small amoeba partly surrounding its nucleus, which is also much enlarged. C, An amœba near the tip of a root hair; the nucleoli are elongated, as they ordinarily are just before nuclear division. D, A root hair filled with meronts. $\mathrm{E}$ and F. Amoebæ in epidermal cells of the root and at the base of root hairs; amobæ about to break up into spores. G, A root hair filled with an amoba. H, A root hair filled with amobre breaking up into spores; the vacuolar channels between each nucleus are plainly visible. $\times 600$ 


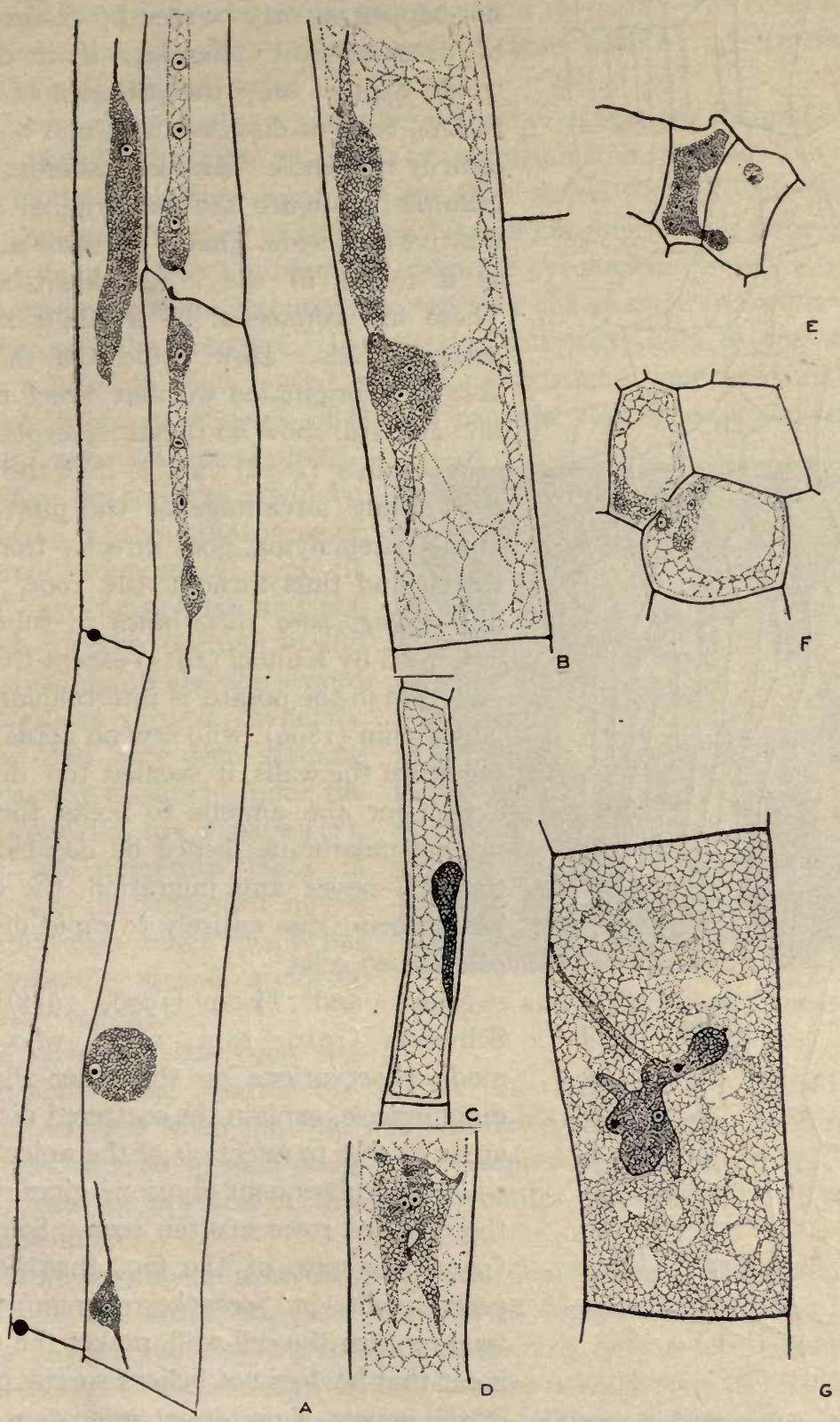

FIg. 105. AM@B E IN THE HOST CELLS

A, B, C, D, and G, Amobæ, with pseudopodia, in recently infected roots. E, Amœbæ in adjoining cells, divided only by the cell walls; this is evidently a case in which penetration occurred, altho no connecting strands are visible. F, Amoba penetrating the cell wall. $X$ I I0 


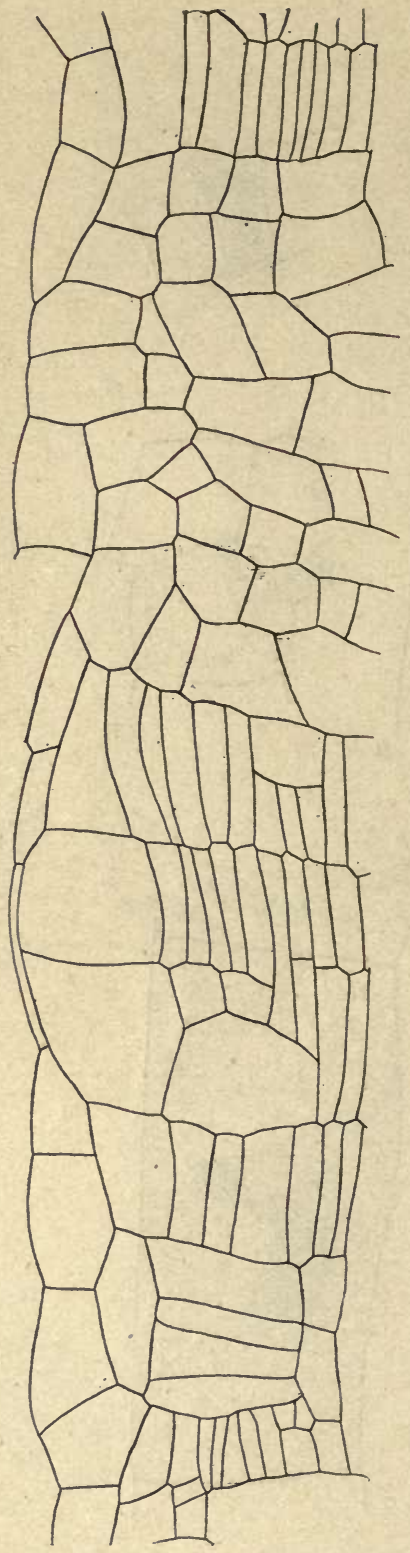

Fig. I06. FORMATION OF "KRANKHEITSHERDE”

All the narrow elongated cells are still uninvaded, but they have increased greatly in number thru outward pressure of the hypertrophied cells. $\times$ rio not happen, as may be seen by examination of cross-sections. Besides, if it did, it would explain only the presence of longitudinal rows of diseased cells, and not necessarily the whole "Krankheitsherde." For example, in figure ro6 the original cortex was five cells wide. That is the same number as is found in the "Krankheitsherde." These are connected by a single row of diseased cells. How could the diseased area have originated without direct migration and still show no radial hyperplasia?

Woronin's (1878) view is that the parasite, taking advantage of the pits found in the parenchyma, goes directly from cell to cell and thus thruout the root, much like Spongospora subterranea in tubers as described by Kunkel (I9I 5) except that the organism in the potato is intercellular. To Nawaschin (I899), who saw no actual passage thru the walls, it seemed too difficult a task for the amœba to break thru the plasma membrane; hence he decided that there is never any migration, the distribution being due entirely to rapid division of diseased cells.

Maire and Tison (I909, I9II) and Schwartz (I9I0, I9II, I9I4), who have made observations on the other Plasmodiophoraceæ, explain the scattered diseased areas as due to infection of the apical cells which by subsequent divisions gives rise to the diseased rows so often seen. Schwartz (IgII), in spite of the fact that he saw pseudopodia in Sorosphaera graminis extending thru the cell wall, makes the statement that he does not believe species of any of the genera show direct migration. $\mathrm{He}$ explains his skepticism on the ground that he never saw any accompanying nucleus in these pseudopodia. 
Lutman (19r3) figures actual passage thru the wall. He believes that the amœbæ are transferred in the cortical tissue both by penetration and by division of the host cells.

It is altogether possible to cut a large number of sections without obtaining any definite clue as to the mode of migration from the root hair to the cortex or the medullary ray, for in the later stages the cell wall acts as a perfect barrier. In view of this fact, Nawaschin might have done enough staining to complete his carefully planned cytological problem without once cutting a root so recently infected that the passage from one cell to another could be detected. During the first two years of the writer's study, only roots that showed evident hypertrophy were used and none of these gave any evidence of such a passage. As soon as the smallest rootlets were sectioned longitudinally, penetration could be observed. It is true that it never appeared abundantly; yet it might have been there and not noticed, for the opening in the wall is so minute and the strand which passes thru is so nearly hyaline that only deep staining will make it apparent under the microscope (fig. I05, F, page 437). There are numerous cases in which it is probable that such a migration has taken place but the connecting strand cannot be seen (fig. I05, E).

The objection has been sug-

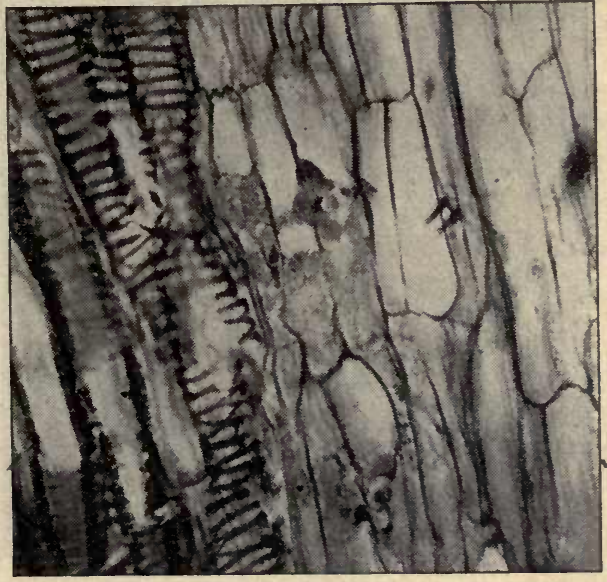

FIG. I07. AMEBA EXTENDING FROM ONE CELL INTO ANOTHER

gested that these strands are merely the remains of a thread which was not severed when the wall was laid down between two dividing cells. This may be true in such cases as are represented in figure 107 , but in other cases the position of the cells precludes the tenability of such an assumption.

Another argument in favor of cell-wall penetration is the shape of the amøba in the initial stages of invasion as compared with that in later stages. When the smallest rootlets, containing only a few diseased cells, are sectioned longitudinally, the amœbæ are usually seen to be elongated and often have pseudopodia extending in different directions. This is never true in a more advanced stage. The amœebæ are then nearly spherical and remain stationary in the cell. This difference is seen on comparison of figures 105 and 108. 
The small offspring at once begins to grow in the newly invaded cell, the process of penetration being repeated while the tissue is still young. From this statement, however, it is not to be inferred that all this occurs while there is no cell division, and that each daughter cell in turn does not become infected. Cell division certainly does take place from the beginning, first in conjunction with penetration and later alone. The result of both methods of invasion is illustrated by figure гоо, в (page 430), which shows a row of eight diseased cells. They extend the same length as three healthy cells. Their relative lengths had been attained before infection occurred; therefore the organism must have passed thru at least two walls, while cell division accounts for the remainder.

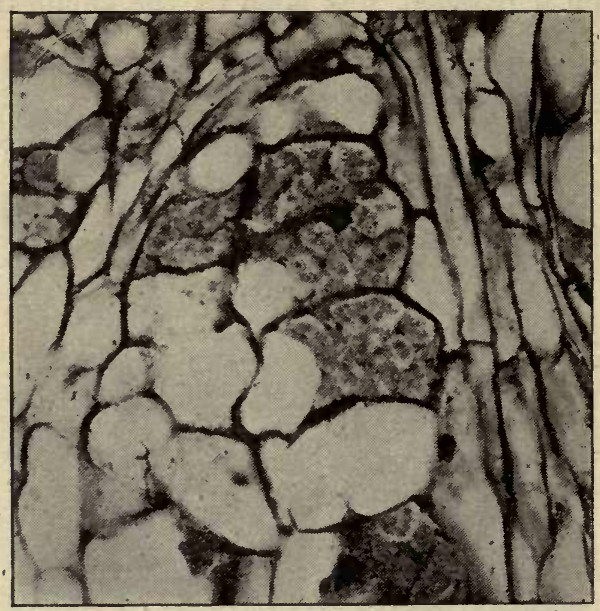

Fig. 108. HOST CELLS FILLED WITH CLOSELy CROWDED AMCEBE

This leads the study to the process of "Krankheitsherde" formation. The whole subject has usually been dismissed with the arbitrary statement that a single cell becomes diseased and then a closely packed group of cells finally results by repeated divisions both anticlinally and periclinally. A cursory study of cross sections would naturally suggest such an explanation, for undoubtedly the diseased areas are arranged in more or less distinct groups. But again longitudinal sections of young and recently infected rootlets may be used to clear up the difficulty and show the initial stages of a typical "Krankheitsherde."

The impression must be avoided that passage thru cell walls is so frequent that a single root-hair infection will suffice to spread the organism thruout the entire affected part of the root. There must be repeated infections, since the amœbæ never migrate far, as the longitudinal sections show. They may enter in almost a straight path as far as the endodermis. The invaded cells may then divide or merely increase in size. Meanwhile the adjoining healthy cells show abnormal division. Nawaschin (I899) explains this hyperplasia on the part of non-invaded cells as due to the mechanical outward pressure of the much-enlarged diseased cells. Eleven rows of uninvaded cells adjacent to a "Krankheitsherde" are shown in figure 106 (page 438); in the healthy part of the root there are only five rows of cells. 
For some unknown reason the amœba in some cases may not penetrate as far as the endodermis, but, after having reached a certain row of the cortical cells, it may pass upward or downward in that row, cell division taking place as fast as invasion occurs. This produces such rows of cells as are illustrated in figure 100 . The vertical direction may be changed at any time and at frequent intervals to a horizontal one, and the adjacent rows thus affected at once begin cell division in each direction. The result is a true "Krankheitsherde." Any one of these diseased rows, or several of them, may extend beyond another group of healthy cells, from which the organism again moves horizontally. This will cause a second " Krankheitsherde," above or below the first and separated by the length of one or more healthy cells. This is illustrated in figure 106 better than it can be described. A single infection may in this manner give rise to from one to probably six "Krankheitsherde," with the intervening uninvaded cells much increased in number over those in the normal tissue.

It has already been pointed out why this longitudinal movement is interpreted as the result of cell-wall penetration instead of as being due to mere division. The diseased area shown in figure 106 is only five rows of cells in width. The perfectly normal tissue of the same root shows exactly the same number of rows. There has been no periclinal division, and therefore direct migration must have taken place.

All this occurs when the root is only a few millimeters in diameter. For some reason the walls finally become impenetrable, and the amœbæ become more nearly globose and later are transformed into masses of spores.

\section{SPORE FORMATION AND SIZE}

For the purpose of this discussion the nuclear phenomena need not be included. The generally accepted explanation of a true mitotic division followed by vacuolar separation into individual uninucleate spores is well known. This separation is supposed to take place almost simultaneously, but stained sections do not always show this to be true. Stages from the amœba to the mature spore are represented in figure 102, D (page 434). In this case there were repeated successive separations instead of simultaneous fission, so that each amoba is divided into two, then four, and so on until no two nuclei longer remain together. The unstained spores in figure I02, A, show the same method of formation. They may then be hexagonal or irregular in outline, and much larger than when mature, but they soon become spherical.

It was surprising to note the wide difference between the actual size of the spores, and the measurements ( $1.6 \mu$ ) given by Woronin (I878) and nearly all succeeding authors. Molliard (1909) gives the diameter 
of the spores as from 1.8 to $2.2 \mu$, and Pinoy (1907), altho he does not state directly, says in speaking of swarm-spores that they are from 3 to $4 \mu$ in diameter.

The measurements made in connection with the present experiments agree more nearly with those of Pinoy for the swarm-spores. The spores in formation, when not yet spherical, measure from 2.5 to $6.9 \mu$ in diameter, being much more variable than those that are older. The smallest mature spore measured was r.9 $\mu$, and the largest was $4.3 \mu$. These measurements include not only living spores but also those stained in various ways. The average was $3.3 \mu$.

\section{A SIMILAR ORGANISM}

For some time the writer was at a loss for an explanation of the occasional presence of from two to twelve strange nuclei in certain root hairs and epidermal cells (fig. I09, A). These are from 3 to $4 \mu$ in diameter,

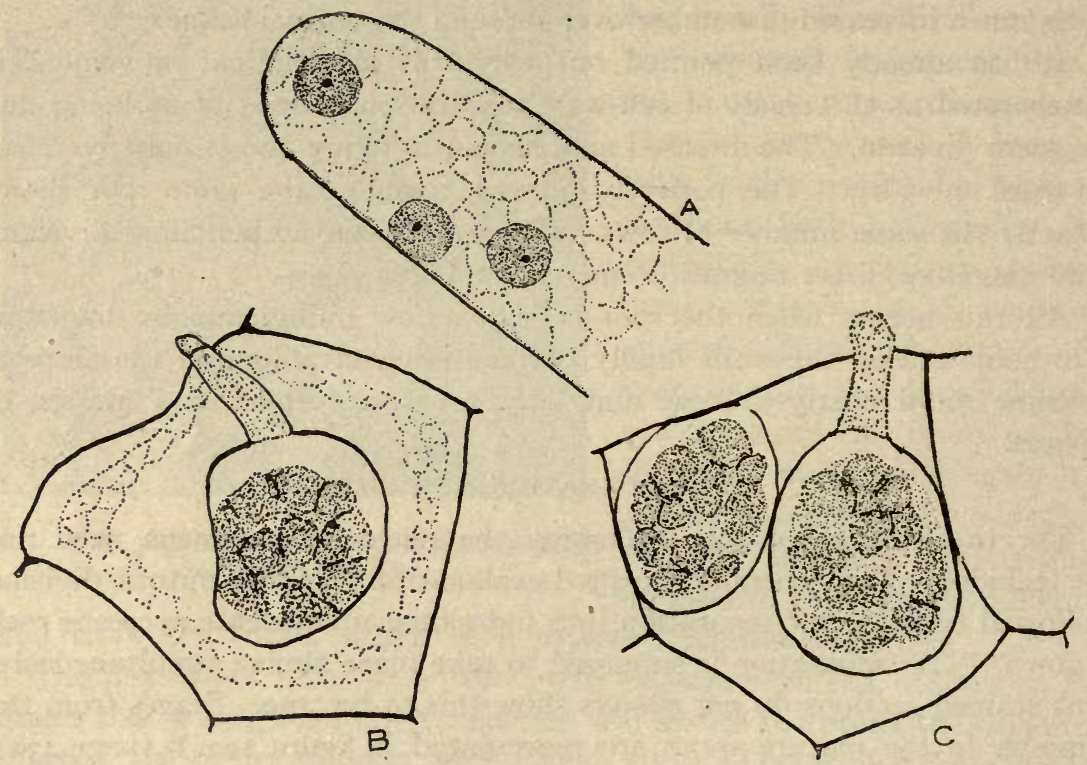

Fig. 109. AN UNKNOWN ORGANISM ASSOCIATED WITH PLASMODIOPHORA BRASSICAE

A, Nuclear-like bodies in a root hair, probably swarm-spores of Olpidium Brassicae; B and C, an unknown organism in the epidermal cells of a cabbage root, probably Olpidium Brassicae. $\times 800$

being smaller than the nuclei of the host cells. The nucleoli have a much denser content than those of the host cells, and are much smaller and less prominent. They appear to be entire swarm-spores containing no visible cytoplasm; however, they do not resemble those of Plasmodiophora Brassicae, being larger, and, most important of all, not having the hyaline zone about the nucleolus which is so characteristic of the latter. 
Furthermore, amxba-like bodies are found in the epidermal cells or the layer next to them, which also look very much like Plasmodiophora but seem to be inclosed in a delicate wall. Stages have been found in which each of these bodies has an appendage, or neck, which protrudes thru the outer epidermal cell wall (fig. Io9, B, c). The organism compares very closely with that described by Woronin (1878) as Synchytrium Brassicae and later by Dangeard (1886) as Olpidium Brassicae. Positive proof of its identity is lacking.

The chytrid never produces any hypertrophy or other outside symptoms by which a diseased plant can be recognized, so that specimens were found only accidentally. For this reason it was impossible to study the swarm-spore stage or the details of the life history of the organism.

The organism evidently enters by way of the root hairs, and never penetrates far into the host. None of the invaded cells are changed in size or general appearance. Even the invaded root hair does not have that slight enlargement which has been mentioned in connection with the entrance of the uninucleate amoba of Plasmodiophora Brassicae.

The fungus can infect a plant that seems perfectly healthy. At least it is not a saprophytic form following the clubroot organism, as roots were sectioned which showed it alone.

\section{BACTERIA IN RELATION TO PLASMODIOPHORA BRASSICAE}

Pinoy's (1902, 1903, 1905, 1907) work with Myxomycetes in their relation to bacteria, and his subsequent suggestion that there is a true symbiosis between the two, represent a very interesting phase in the study of Plasmodiophora. It has long been held that certain saprophytic slime molds feed on accompanying organisms, and the data at hand seem entirely plausible. Lister (1894) has seen the ingestion of bacteria by active swarm-spores. The experiments of Vuillemin (I903), Nadson (IgOI), and Potts (1902) show that Dictyostelium mucoroides Bref. feeds directly on bacterial colonies and destroys a large number of these at fruiting time.

The general conditions of subsistence governing saprophytic forms and those controlling parasitic organisms are not the same, however; so that from a priori reasoning it would seem justifiable to say that Plasinodiophora Brassicae needs no concomitant organism in its life cycle. Yet the case is not so clear, since, on examination of nearly every root that has been diseased for some time, such an organism is found to be present. When the surface of these roots is sterilized and placed in agar, they may show no indication of bacteria until they are cut in two and the fresh surface is placed in contact with the medium. Moreover, E. F. 
Smith (I9II) and Eycleshymer (I894), both careful workers, state that they saw these bacteria. This is also in accordance with what Maire and Tison (IgII) claim to be true for certain parasitic slime molds that are able to ingest unicellular algæ present in their aquatic host; and with what Kunkel (I9I5) has demonstrated in the case of Spongospora subterranea grown on agar in which pure cultures of plasmodia become abnormal and die, while those with which bacteria are present live and thrive.

All of Pinoy's (1905) experiments appear to corroborate his idea that a coccus form enters the root with the swarm-spore and lives in constant association with the parasite thruout its entire life cycle. He stained sections of the root and observed bacterial forms within the cells. They appeared so much like parts of the cell contents that the microscopical analysis had to be accompanied by cultural study. For this he procured diseased roots of Brassica sinensis measuring from eight to ten centimeters in diameter, seared the outside, and cut plugs from the interior by means of a flamed pipette. When these plugs were planted in agar media, numerous colonies of bacteria soon appeared. To prove that these organisms were necessary for the development of the myxomycete, Pinoy placed spores of Plasmodiophora Brassicae in a large number of test tubes containing sterilized extract of roots. In two tubes the spores were accidentally not associated with bacteria and they failed to germinate, while in all the other tubes the spores did germinate.

Pinoy's results are interesting, altho the work does not appear to be extensive enough to warrant the conclusion he has drawn. The following experiments were undertaken by the writer in further quest for facts bearing on this problem:

Thruout three years of study almost five hundred petri-dish and testtube cultures have been made from diseased roots of all sizes and ages, grown under various conditions and in widely separated localities. The ordinary method of procedure was to place the roots for ten minutes in mercuric chloride I-I 000 ; then, after rinsing them several times in sterilized distilled water, to break the roots open and remove bits of the diseased tissue from the broken surface by means of a flamed scalpel. The bits of roots were placed in a sterilized petri dish, where they were teased apart in a few drops of sterilized distilled water. Two successive dilutions were made, and these, together with the original drop in which the tissue had been crushed, were poured into nutrient agar media.

All the results were uniform in that no bacterial colonies were obtained from the roots with young swellings. From the medium-sized swellings occasional colonies developed; and from the larger galls, especially when the epidermis had been broken, numerous colonies always appeared. 
The fact that only the small swellings show no contamination might be attributed to the penetration of the mercuric chloride. In order to avoid this source of error, the time of treatment was reduced from ten minutes to five, and even to three, or was dispensed with entirely, the roots being soaked for three hours in water that had been standing over calcium hypochlorite for two hours and then decanted. The results were the same.

Another possible hindrance to the appearance of colonies at first might have been the medium, which was nutrient agar. In order to eliminate this objection, later cultures were made both in potato agar and in a medium made from the extract of healthy cabbage roots like that used successfully by Kleimenov (I9I2). No bacterial growths were obtained.

Bacteria have been found in large roots similar to those that Pinoy used; but Pinoy obtained a coccus, while the most prevalent form in the cultures of the writer has been a very motile rod-shaped bacterium producing yellowish, opalescent colonies on the various media. In test tubes containing disinfected diseased roots this organism readily produces a soft rot and thus liberates the spores of the slime mold. It is well known that the epidermis is soon ruptured after swelling begins, and from all indications the conditions are propitious for the entrance of any organisms that may be in the soil. This is doubly true for any that find exposed cabbage tissue a favorable substratum on which to reproduce. as does evidently the bacterium mentioned above. These series of cultures tend to show that bacteria do not enter with the swarm-spore, as Pinoy (1905) believes, but that the disease must advance to a certain stage before the bacteria can gain entrance. The above experiments are perhaps in themselves not sufficient proof, especially since they bear on the negative side of the question. To these, however, are to be added the following data:

The writer has found that spores germinate better if they have been exposed to cold or to drying for a short time before being placed in a warm oven at a temperature of from $27^{\circ}$ to $30^{\circ} \mathrm{C}$.; and that the best medium tested is water that has been filtered thru muck soil. Accordingly diseased roots were washed, treated with either mercuric chloride or calcium hypochlorite, placed in sterilized, cotton-plugged test tubes, and left in the ice box for seven days. At the end of that time they were cut into pieces with a flamed scalpel and some of the sterilized muck filtrate was added, after which the roots were placed in the incubator for six hours. Before making mounts to examine the material, a loopful of the filtrate was transferred to each of two petri dishes, which were then poured with nutrient agar. This was done in order to determine with certainty whether or not bacteria were present. Germination was fully as good when the bacteria were not present as when they were. This is in direct 
opposition to Pinoy's (1905) statement that there is no development when the spores are not accompanied by a coccus.

Diseased cabbage roots were disinfected with either mercuric chloride or calcium hypochlorite; if with the former, they were then rinsed three times carefully in different tubes of sterilized distilled water; if with the latter, they were rinsed in muck-soil filtrate, which is acid and tends to neutralize any of the calcium compounds that might adhere to the roots and retard germination of the spores. All the roots were then either transferred to tubes of nutrient agar slants or embedded in agar in petri dishes. If at the end of a week they showed no signs of contamination, those in the petri dishes were placed on agar slants, after which all the roots were minced and left for another week in order to make sure that no bacteria were in the roots and had been liberated by the mincing.

Seeds of the cabbage were sterilized by the same method as was employed for the roots, but they were not rinsed in sterilized water when calcium hypochlorite was used. The seeds were planted in nutrient agar in petri dishes and the young plants were permitted to develop until they were free of the old seed coats. They were then placed in the tubes with the minced roots that showed no bacterial colonies, and a sufficient amount of the sterilized muck filtrate was added to insure spore germination but not enough to injure the small seedlings.

This process, tho complicated and long, seems to fulfill all the requirements that carefulness demands; and in the three series tried, from five to twenty per cent of the cultures were free from bacteria. The chief difficulty lies in the fact that there is such a narrow margin between spore formation and bacterial invasion that it is hard to select swellings which are neither too young to contain mature spores nor yet so old that bacteria have entered. One objection to the experiment is obvious. There is no way of determining contaminations except by the absence of colonies on the agar where the roots have been minced and on which the seedlings grow. Yet it seems hardly possible that bacteria can be present thruout all these operations and not come into contact with the medium. Besides, where no bacterial colonies appear, the plants grow more vigorously, produce larger roots, and show infection sooner than in the contaminated tubes. Swellings apparent to the naked eye were formed at the end of five days the first time the experiment was tried. When the plants were fixed, sectioned, and stained, they showed amœbæ in the cortex as well as in a large number of root hairs; all of which tends to discount Pinoy's (I905) belief that there is no development of the parasites without a concomitant bacterium.

Pinoy based his conclusions in part on the evidence presented by stained sections. Apparently he studied sections of large roots, since the roots 
that he received from Mangin were evidently eight or more centimeters in diameter. The writer was unable to procure thionine, the stain that Pinoy used, but he tried both Ziehl's carbol fuchsin and Kuehne's carbol methylene blue, which have always given good results in staining parasitic bacteria in other tissue. Parts of small, slightly swollen roots, as well as pieces of larger roots (of which some were still normal in color and others had begun to turn black), were fixed in Carnoy's fluid, consisting of glacial acetic acid and alcohol. The small, slightly swollen roots after staining showed no signs of bacteria. Pinoy (1905) states
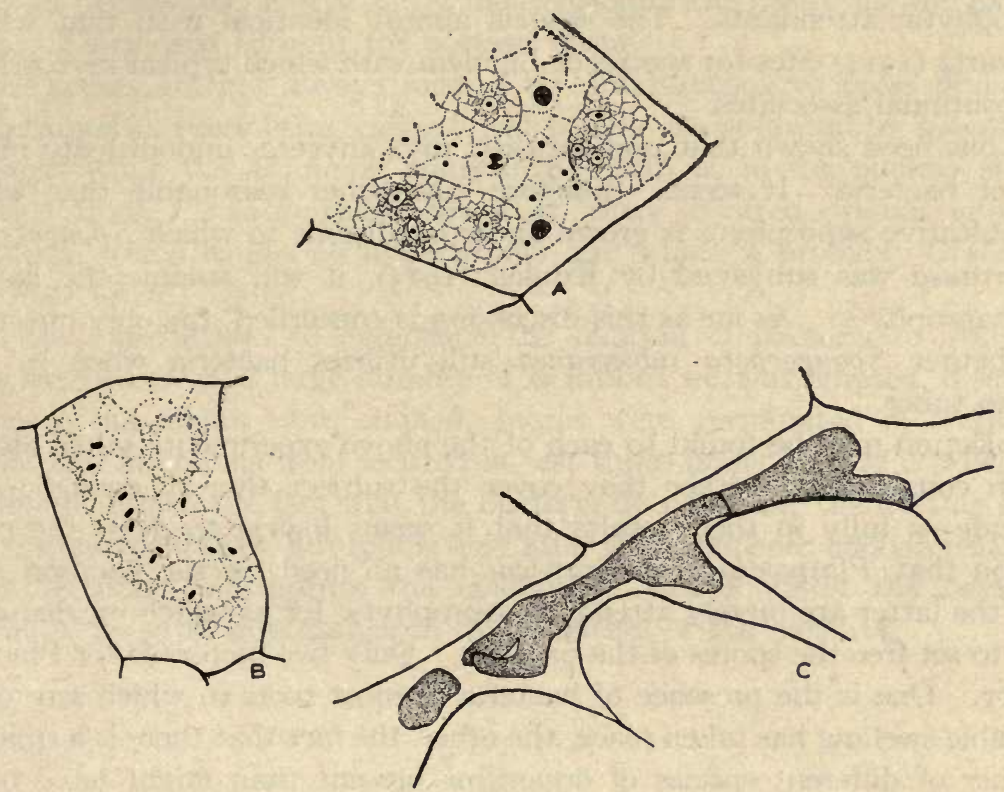

FIg. I IO. SAPROPHYTIC ORGANISMS IN DISEASED TISSUE

A, Partly corroded starch grains between the amœbæ, the refractive hila being the only visible part in some of them; B, bacteria in a cell of diseased tissue; C, mycelium of a saprophytic fungus in darkened diseased tissue. $\times 800$

that cocci appear as very refractive bodies among the amœbæ. In this experiment, the hila of partly corroded starch grains (fig. I Io, A) appeared in several instances as spherical, brightly stained bodies; but they could hardly be mistaken for an organism, as the same effect is shown in healthy cells in which entire starch grains may be seen.

The older, diseased tissue that has not yet turned dark presents a somewhat different appearance from that of the youngest swellings. The epidermal cells are torn in many places, and rod-shaped bacteria (fig. I Io, B) are found both within and between the cells. Many of these cells show broken passages in the walls where the organism could easily have entered. 
In a blackened root the only additional change that can be recognized is the presence of hyphr. This blackness is almost a true criterion of the effects of a fungus, for the bacteria seldom, if ever, produce any pronounced discoloration (fig. I I o, c).

It is not altogether a new phenomenon to find other organisms following parasitic slime molds. For example, the earlier writers who described Sorosphaera Veronica regarded it as a rust because of the mycelial threads which, according to these investigators, are constantly present. Maire and Tison (1909) prove with but little difficulty that the fungi are merely saprophytic attendants. The case is almost identical with that which Schwartz (I9I4) cites for species of Ligniera with which typical mycorrhiza are continual associates.

It has been shown that non-parasitic myxomycetes undoubtedly make use of bacteria. It seems, therefore, altogether reasonable that when a facultative saprophyte is grown under conditions to which Spongospora subterranea was subjected by Kunkel (I9I5), it will assume the habits of a saprophyte. As far as this discussion is concerned, the only question is whether Spongospora subterranea still utilizes bacteria when in the potato tuber.

Objection may be found to each of the above experiments taken alone. When considered together they cover the subject thoroly enough, and coincide so fully in their results that it seems logical to draw the conclusion that Plasmodiophora Brassicae has no need for the bacteria and that the latter are merely attendant saprophytic forms which incidentally help to set free the spores of the parasite. Only two factors favor Pinoy's theory. One is the presence of bacteria in most roots in which any considerable swelling has taken place; the other, the fact that there is a smaller number of different species of organisms present than might have been expected. Almost invariably the rod-shaped bacterium forming opalescent colonies on nutrient agar was the only one isolated. The facts, however. that spores can germinate in sterilized media, that infection can occur on seedlings in test tubes on nutrient agar where no bacterial colonies are present, and that recently infected roots never show bacteria either when tested in culture or under the microscope after staining, would seem to offset any evidence that heretofore has been adduced to the contrary. Therefore it seems evident that Plasmodiophora Brassicae is an obligate parasite, and, as such, needs no other food supply than that furnished by its host.

\section{SUMMARY}

Neither the motility of swarm-spores nor the action of winds is an important factor in the dissemination of Plasmodiophora Brassicae. 
Spores germinate better after a slight rest period and in such a medium as muck-soil filtrate. Each spore produces one swarm-spore, which, if not supplied with a host, develops no further.

It is difficult to stain the flagella of swarm-spores, but if they are first killed instantly with fumes of osmic acid fairly good mounts can be obtained.

Penetration takes place thru the wall of the root hair while the organism is in a uninucleate stage. The root hair at once shows hypertrophy. The amœba increases in size as it passes rootward, and finally, by direct cell-wall penetration as well as by the division of the host cells, the pathogene is distributed thruout the cortical tissue.

The spores are not always formed by simultaneous vacuolar divisions of the amobæ, there being cases in which they are produced by successive divisions while the adjoining amœbæ may still be in the nuclear stage.

Aside from Plasmodiophora Brassicae, there is often present another organism, which causes no hypertrophy and which is probably Olpidium Brassicae (Wor.) Dang.

In the experiments to determine the relation of bacteria to Plasmodiophora Brassicae, a large number of isolations were attempted, diseased tissues of all stages were stained, spores were germinated in sterilized media, and infections were secured in test tubes under aseptic conditions. All this points to the fact that the bacteria do not enter the host as soon as the slime mold does, but follow only after there has been enough enlargement of tissues to rupture the epidermis. Consequently the bacteria can be of no vital importance in the nutrition of the parasite. 



\section{BIBLIOGRAPHY}

Atkinson, G. F. Club root of cabbage. In Botanical notes. South Carolina Exp. Sta. Ann. rept. I: I5-18. I889.

Carruthers, William. Anbury, club-root, or finger and toe. Roy. Agr. Soc. England. Journ. 3:4:334-339. I 893 .

DANGEARD, P.-A. Olpidium. In Recherches sur les organismes inférieurs. Ann. sci. nat. (Bot.) 7:4:327. I886.

Eycleshymer, A. C. Club-root in the United States. Journ. myc. $7: 79-88, \mathrm{Pl} . \mathrm{xv}-\mathrm{xvr}$. $\mathrm{r} 894$.

Hulst, George D. Club root. In Insects injurious to the cabbage and the best means of preventing their ravages. New Jersey Agr. Coll. Exp. Sta. Bul. 50:14-21. I888.

Humphrey, Jas. Ellis. The club root of cabbages. In Department of Vegetable Physiology, Report. Massachusetts Agr. Exp. Sta. Rept. 9:230-23I. I 892 .

Kleimenov, P. D. [Russian title.] Clubroot of cabbage (Plasmodiophora Brassicae Woron.). In Subjects of studies of fungous parasites of cultivated plants of the Moscow government. Report on phytopathological researches made in r9r 2 by K. E. Nurashkinsky and P. D. Kleimenov. Moscow Government's Zemstvo, Second paper, p. 26-37. (Abstracted by C. D. Sherbakoff.) I9I2.

Kunkel, L. O. A contribution to the life history of Spongospora subterranea. Journ. agr. res. 4:265-278, P1. Xxxix-XLIIr. I9I5.

Lister, Arthur. A monograph of the Mycetozoa, p. I-224. (Reference on p. 4.) 1894 .

Lutman, B. F. Studies on club-root. I. The relation of Plasmodiophora Brassicae to its host and the structure and growth of its plasmodium. Vermont Agr. Exp. Sta. Bul. I75:I-27, P1. I-IV. I9I3.

Maire, René, et Tison, Adrien. La cytologie des Plasmodiophoracées et la classe des Phytomyxinae. Ann. myc. 7:226-253, P1. IV-vi. I909.

Nouvelles recherches sur les Plasmodiophoracées. Ann. myc. 9:226-246, Pl. X-XIv. I9I I.

Mangin, L. Le gros-pied ou hernie du chou. Rev. hort. 74:432-435. 1902.

Massee, Geo. Club-root. Gard. chron. 3:34:351-352. I903.

Molliard, M. Une nouvelle Plasmodiophorée, parasite du Triglochin palustre L. Soc. bot. France. Bul. 56:23-25. 1909 .

Nadson, G. A. Des cultures du Dictyostelium mucoroides Bref. et des cultures pures des Amoebes en général. Scripta Botanica (St. Petersburg) 15: I-38. Abstracted in Just's Bot. Jahresber. 27 186 . I90I. 
Nawaschin, S. Beobachtungen über den feineren Bau und Umwandlungen von Plasmodiophora Brassicae Woron. im Laufe ihres intracellularen Lebens. Flora 86:404-427, P1. Xx. $\quad$ I899.

Pinoy, ERnest. Nécessité de la présence d'une bactérie pour obtenir la culture de certains myxomycètes. (Note préliminaire.) Soc. Myc. France. Bul. 18:288-290. I902.

Nécessité d'une symbiose microbienne pour obtenir la culture des Myxomycètes. Acad. Sci. (Paris). Compt. rend. 137: 580581. I903.

Rôle des bactéries dans le développement du Plasmodiophora brassicæ, myxomycète parasite produisant la hernie du chou.

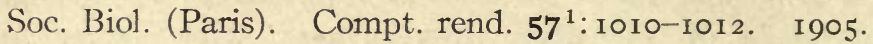

Rôle des bactéries dans le développement de certains myxomycètes. Inst. Pasteur. Ann. 21:622-656, 686-700, Pl. xIII-Xvi. 1907 .

Potts, George. Zur Physiologie des Dictyostelium mucoroides. Flora 9I:28I-347. I902.

Prowazek, S. Über den Erreger der Kohlhernie Plasmodiophora brassicae Woronin und die Einschlüsse in den Carcinomzellen. Kais. Gesundheitsamte. Arb. 22:396-410. 1905.

Schwartz, E. J. Parasitic root diseases of the Juncaceae. Ann. but. 24:51 I-522, Pl. XL. 1910.

Ann. bot. $25^{2}: 79$ I-797, Pi. LXI. I9I I.

The life-history and cytology of Sorosphaera Graminis.

The Plasmodiophoraceae and their relationship to the Mycetozoa and the Chytrideae. Ann. bot. 28:227-240, Pl. XII. I9I4. SMITH, Erwin F. Bacteria with myxomycetes. In Bacteria in relation to plant diseases $2: 169-172$. I9II.

Smith, Worthington G. Club-root of turnips, cabbages, mangels, and allied plants. In Diseases of field and garden crops, p. 94-104. I884. Somerville, William. Further infection experiments with finger-andtoe. Roy. Agr. Soc. England. Journ. 3:6:749-759. I 895.

Vuillemin, Paul. Une Acrasiée bactériophage. Acad. Sci. (Paris). Compt. rend. 137:387-389. I903.

Wrnge, Ö. Cytological studies in the Plasmodiophoraceæ. Ark. bot. I2 $2^{9}:$ I-39, pl. I-3. I9I3.

Woronin, M. Plasmodiophora Brassicae, Urheber der KohlpflanzenHernie. Jahrb. wiss. Bot. [Pringsheim] II : $548-574$, Pl. xxIx-XxxIv. 1878 . 




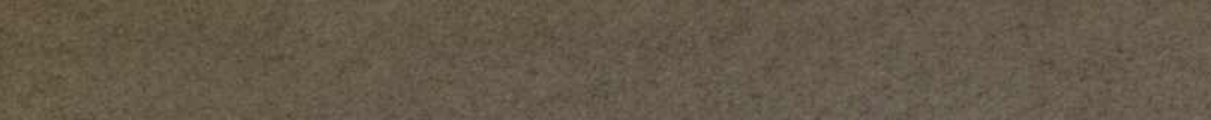

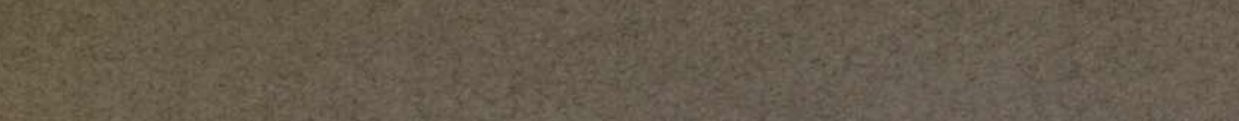

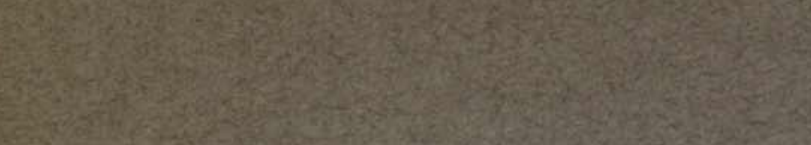

86

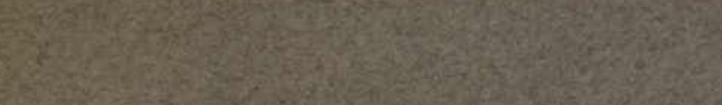
(5)
(1)

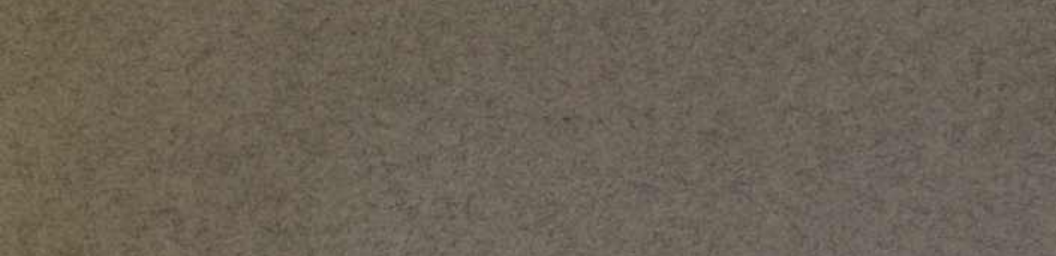

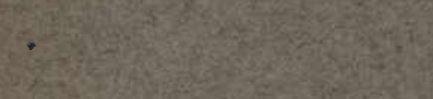

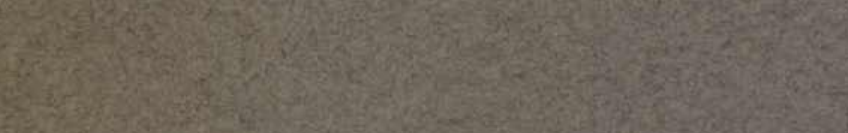

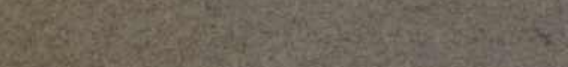
5.

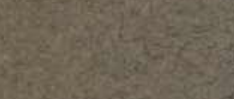
a.

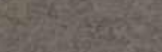
(a)
3.

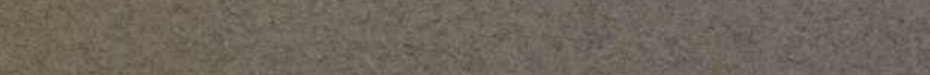

ation

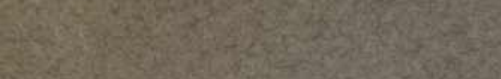

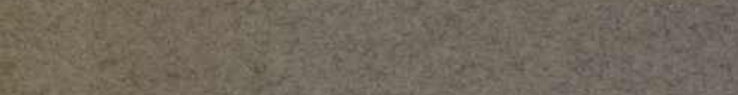

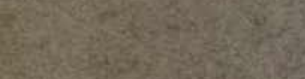

(2)

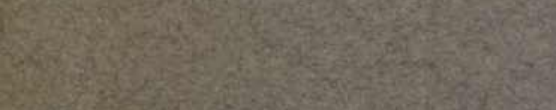

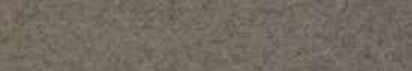

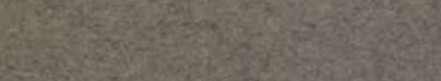

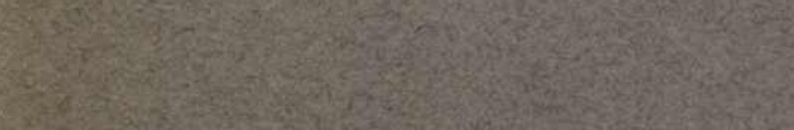

(2)

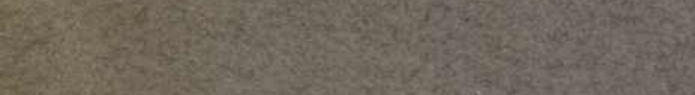

6.

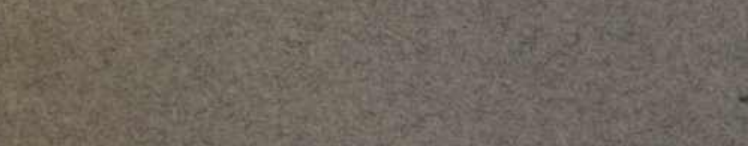

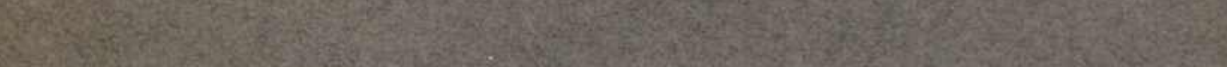

tons

- 
sosis: 3

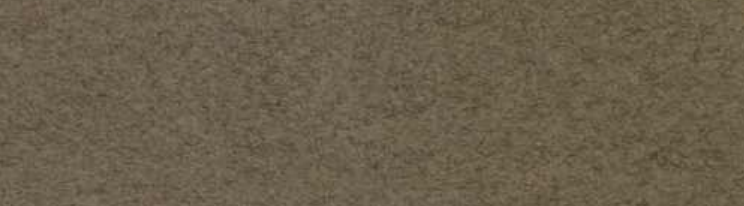

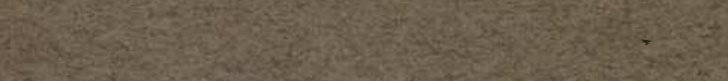

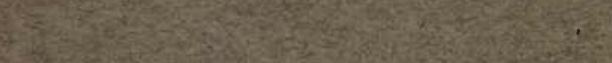




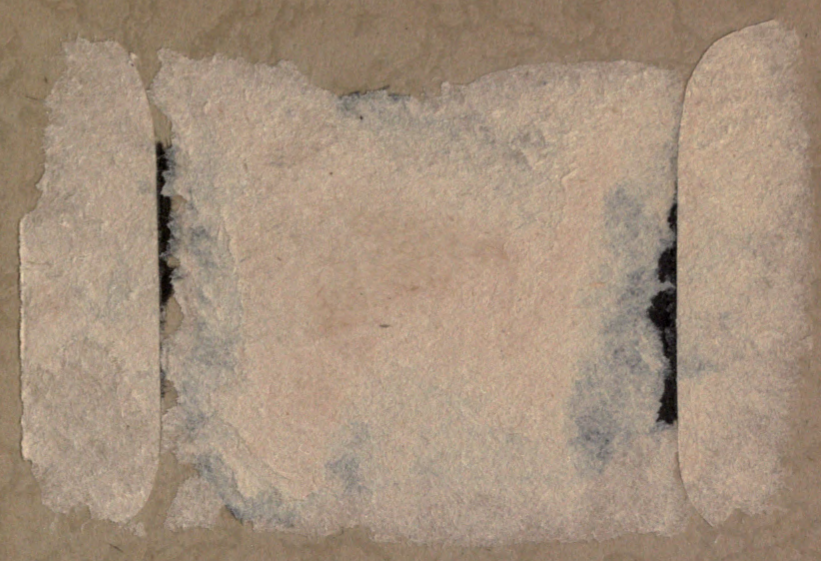


